Nevada

Environmental

Restoration

Project

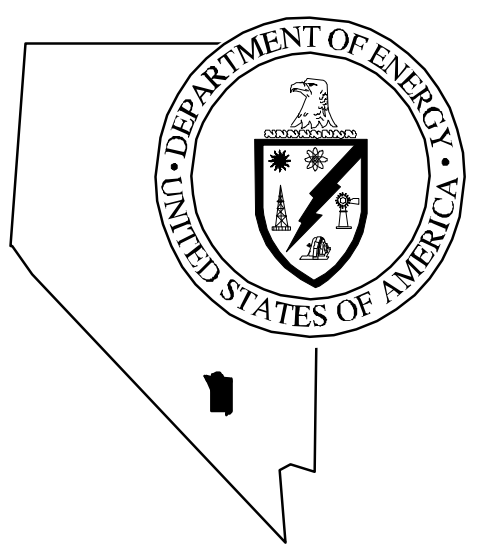

Corrective Action Investigation Plan

for Corrective Action Unit 321 :

Area 22 W eather Station Fuel Storage,

$\mathrm{N}$ evada Test $\mathrm{S}$ ite, $\mathrm{N}$ evada

Controlled Copy $\mathrm{N} 0$ ::

Revision N 0.: 0

J anuary 1999

Approved for public release; further dissemination unlimited.

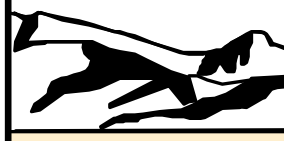

Environm ental Restoration

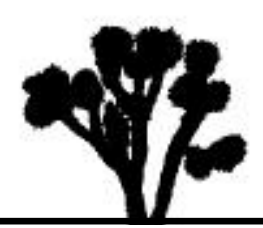

Division 
Available to the public from -

\author{
U.S. Department of Commerce \\ National Technical Information Service \\ 5285 Port Royal Road \\ Springfield, VA 22161 \\ (703) 487-4650
}

Available electronically at http://www.doe.gov/bridge. Available to U.S. Department of Energy and its contractors in paper from -
U.S. Department of Energy
Office of Scientific and Technical Information
P.O. Box 62
Oak Ridge, TN 37831-0062
(423) 576-8401

Reference herein to any specific commercial product, process, or service by trade name, trademark, manufacturer, or otherwise, does not necessarily constitute or imply its endorsement, recommendation, or favoring by the United States Government or any agency thereof or its contractors or subcontractors. 


\title{
CORRECTIVE ACTION INVESTIGATION PLAN FOR CORRECTIVE ACTION UNIT 321: AREA 22 WEATHER STATION FUEL STORAGE, NEVADA TEST SITE, NEVADA
}

\author{
DOE Nevada Operations Office \\ Las Vegas, Nevada
}

Controlled Copy No.:

Revision No.: 0

January 1999

Approved for public release; further dissemination is unlimited. 


\section{CORRECTIVE ACTION INVESTIGATION PLAN FOR CORRECTIVE ACTION UNIT 321: AREA 22 WEATHER STATION FUEL STORAGE, NEVADA TEST SITE, NEVADA}

Approved by:

Signature Approved

Date:

$1 / 8 / 99$

Janet Appenzeller-Wing, Project Manager

Industrial Sites Project

Approved by:

Signature Approved

Date:

Runore C. Wycoff, Division Director

Environmental Restoration Division 


\section{Table of Contents}

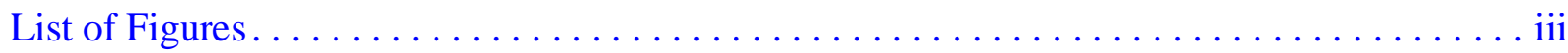

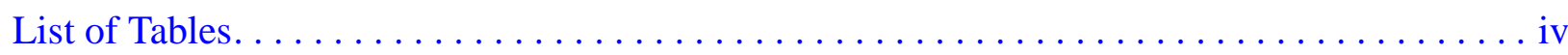

List of Acronyms and Abbreviations $\ldots \ldots \ldots \ldots \ldots \ldots \ldots \ldots \ldots \ldots \ldots \ldots \ldots \ldots \ldots \ldots \ldots \ldots$

Executive Summary . . . . . . . . . . . . . . . . . . . . . . . . . ES-1

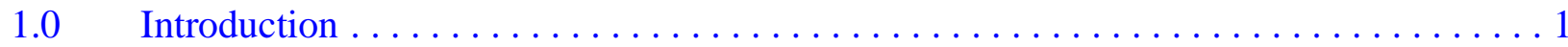

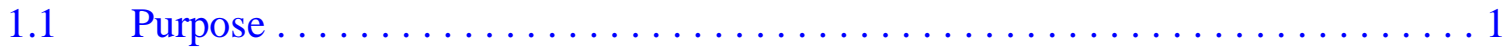

$1.2 \quad$ Scope. .................................. 4

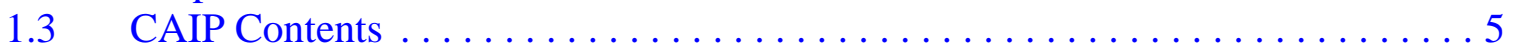

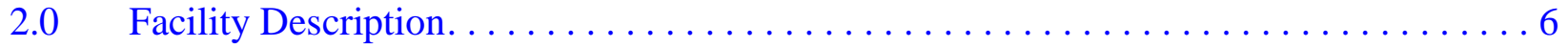

$2.1 \quad$ Physical Setting. . . . . . . . . . . . . . . . . . . . . . 6

2.2 Operational History. . . . . . . . . . . . . . . . . . . . . . . 7

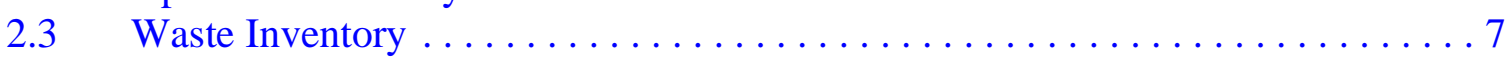

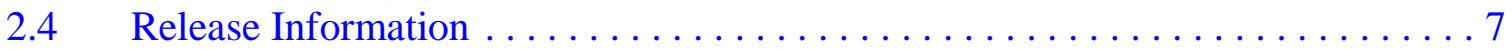

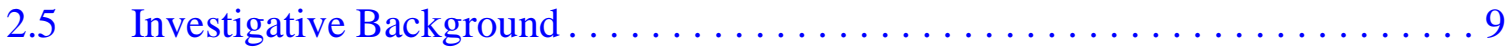

3.0 Objectives . . . . . . . . . . . . . . . . . . . . . 10

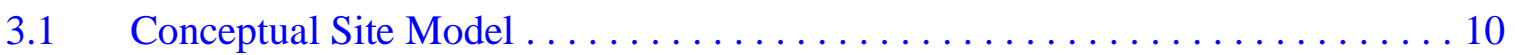

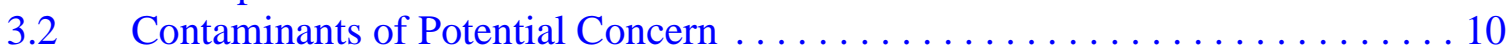

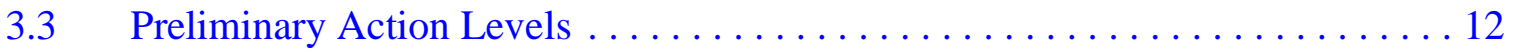

3.3.1 Field Screening Levels . . . . . . . . . . . . . . . . . . . . . 12

3.3.2 Chemical Preliminary Action Levels . . . . . . . . . . . . . . . . . . . . 13

3.3.3 Radiological Preliminary Action Levels. . . . . . . . . . . . . . . . . 13

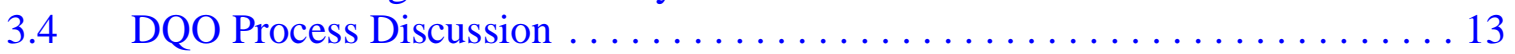

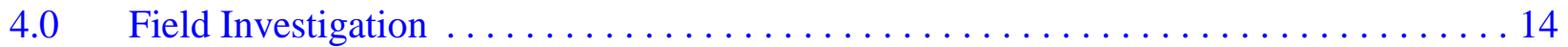

$4.1 \quad$ Sampling Strategy. . . . . . . . . . . . . . . . . . . . 15

4.1.1 Sampling Locations . . . . . . . . . . . . . . . . . . 15

4.1.1.1 Field Screening Confidence Levels for the

Hanby Method ........................ 15

4.1.1.2 Nondetect-Field-Screening Samples and

Laboratory Confidence Levels . . . . . . . . . . . 17

4.1 .2 Soil Sampling . . . . . . . . . . . . . . . . . . 17

4.1 .3 Field Screening and Field Surveys . . . . . . . . . . . . . . . 18

4.1.4 Sample Selection for Laboratory Analyses . . . . . . . . . . . . . . . 18

4.2 Sample Collection and Decontamination Procedures. . . . . . . . . . . . . . . 19

4.2.1 Quality Control Samples. . . . . . . . . . . . . . . . . . . . . . . . 19 


\section{Table of Contents (Continued)}

$5.0 \quad$ Waste Management. ....................................... 20

$5.1 \quad$ Waste Minimization ................................. 20

$5.2 \quad$ Potential Waste Streams . . . . . . . . . . . . . . . . . . . . . 20

$5.3 \quad$ Investigation-Derived Waste Management $\ldots \ldots \ldots \ldots \ldots \ldots \ldots \ldots \ldots \ldots \ldots \ldots \ldots$

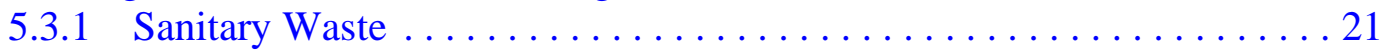

5.3.2 Low-Level Radioactive Waste . . . . . . . . . . . . . . . . . . 21

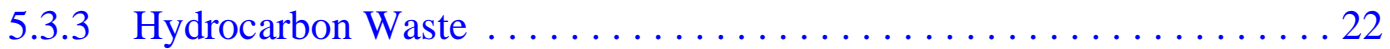

5.3 .4 Hazardous Waste .................................. 22

5.3.5 Mixed Waste Management....................... 23

$6.0 \quad$ Duration and Records Availability . . . . . . . . . . . . . . . . . . . 25

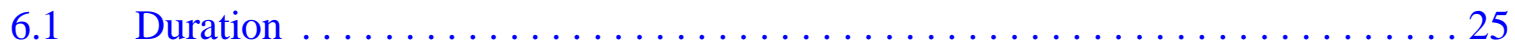

$6.2 \quad$ Records Availability ................................... 25

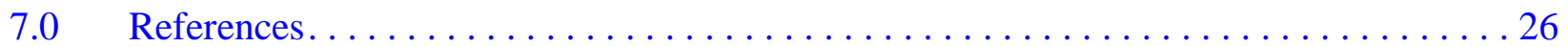

\section{Appendix A - Data Quality Objectives Worksheets}

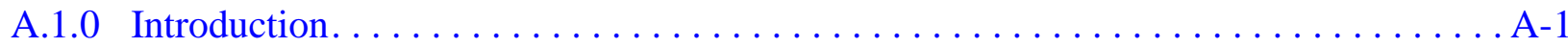

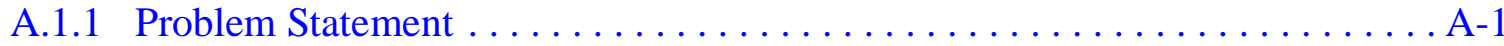

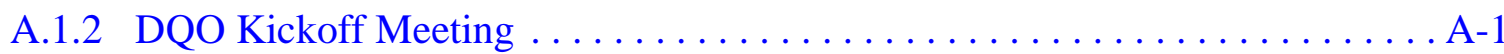

A.2.0 Conceptual Model .................................. A-3

A.3.0 Potential Contaminants . . . . . . . . . . . . . . . . . . . . . . . . . . . . . . . . . . . A -5

A.4.0 Decisions and Inputs . . . . . . . . . . . . . . . . . . .

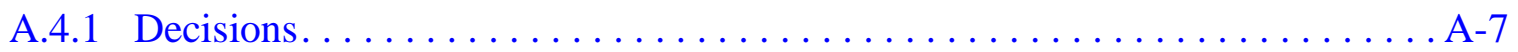

A.4.2 Inputs and Strategy $\ldots \ldots \ldots \ldots \ldots \ldots \ldots \ldots \ldots \ldots \ldots \ldots \ldots \ldots \ldots \ldots \ldots \ldots \ldots \ldots \ldots$

A.5.0 Investigation Strategy ................................. A-11

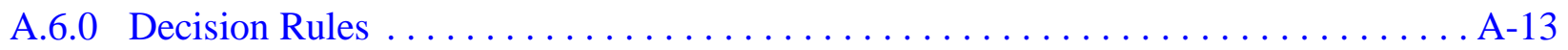

A.7.0 Decision Error. . . . . . . . . . . . . . . . . . . . . . . . . . . A 15

A.7.1 Initial Field Screening. ..........................

A.7.2 Laboratory Confirmation of Field Screening Nondetections ............. A-15

\section{Appendix B - Project Organization}

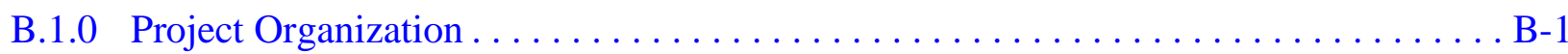




\section{List of Figures}

Number

1-1 Nevada Test Site and CAU 321 Fuel Storage Area Location Map, Nevada. . . . . . 2

1-2 CAU 321 Fuel Storage Area Location Map, Nevada Test Site. . . . . . . . . . . . . 3

2-1 1955 Aerial Photograph of the CAU 321 Fuel Storage Area . . . . . . . . . 8

4-1 Soil Sampling Locations for the CAU 321 Fuel Storage Area . . . . . . . . . . . 16

A.6-1 Decision Rule Logic Diagram for CAU 321 Fuel Storage

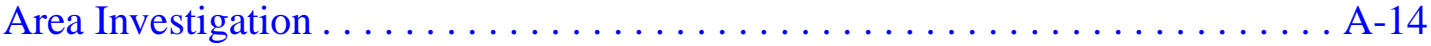




\section{List of Tables}

Number

3-1 Laboratory Analytical Requirements for CAU 321 Fuel Storage Area . . . . . . . 11

A.1-1 DQO Kickoff Meeting Participants. ....................... A-2

A.2-1 Conceptual Model Element Descriptions . . . . . . . . . . . . . A-4

A.3-1 CAU 321 Fuel Storage Area Contaminants of Potential Concern . . . . . . . . . A-6

A.4-1 Decisions, Inputs, and General Strategies . . . . . . . . . . . . A-8 


\section{List of Acronyms and Abbreviations}

bgs $\quad$ Below ground surface

BN Bechtel Nevada

CADD Corrective Action Decision Document

CADD/CR Corrective Action Decision Document/Closure Report

CAIP Corrective Action Investigation Plan

CAS Corrective Action Site(s)

CAU Corrective Action Unit

CFR Code of Federal Regulations

CLP Contract laboratory program

$\mathrm{cm} \quad$ Centimeter(s)

COPC Contaminant(s) of potential concern

CV Coefficient of variation

DOE U.S. Department of Energy

DOE/NV U.S. Department of Energy, Nevada Operations Office

DOT U.S. Department of Transportation

DQO Data Quality Objective(s)

EPA U.S. Environmental Protection Agency

FFACO Federal Facility Agreement and Consent Order

FSL Field screening levels

$\mathrm{ft} \quad$ Foot (feet)

HASP Health and Safety Plan

HWAA Hazardous waste accumulation area

IDW Investigation-derived waste

in. $\quad \operatorname{Inch}(\mathrm{es})$

IT IT Corporation

ITLV IT Corporation, Las Vegas 


\title{
List of Acronyms and Abbreviations (Continued)
}

\author{
$\mathrm{km} \quad$ Kilometer(s) \\ LLW Low-level radioactive waste \\ m Meter(s) \\ mi Mile(s) \\ $\mathrm{mg} / \mathrm{kg} \quad$ Milligram(s) per kilogram \\ $\mathrm{mg} / \mathrm{L} \quad$ Milligram(s) per liter \\ $\mu \mathrm{g} / \mathrm{L} \quad$ Micrograms per liter \\ MARSSIM Multi-Agency Radiation Survey and Site Investigation Manual \\ MS/MSD Matrix Spike/Matrix Spike Duplicate \\ NAC Nevada Administrative Code \\ NDEP Nevada Division of Environmental Protection \\ NEPA National Environmental Policy Act \\ NRC U.S. Nuclear Regulatory Commission \\ NTS Nevada Test Site \\ NTSWAC Nevada Test Site Waste Acceptance Criteria \\ PAL Preliminary action levels \\ PCB Polychlorinated biphenyl(s) \\ PPE Personal protective equipment \\ ppm Part(s) per million \\ PRG Preliminary remediation goal(s) \\ QA/QC Quality assurance/quality control \\ QAPP Quality Assurance Project Plan \\ RCRA Resource Conservation and Recovery Act \\ RPD Relative percent difference \\ SAIC Science Applications International Corporation \\ SOW Statement of Work
}




\section{List of Acronyms and Abbreviations (Continued)}

SSHASP Site-specific health and safety plan

SVOC Semivolatile organic compound(s)

TCLP Toxicity Characteristic Leaching Procedure

TID Tamper-indicating device(s)

TPH Total petroleum hydrocarbon(s)

VOC Volatile organic compounds

$\%$ R Percent Recovery 


\section{Executive Summary}

The Corrective Action Investigation Plan for Corrective Action Unit 321, Area 22 Weather Station Fuel Storage, Corrective Action Site 22-99-05, Fuel Storage Area, at the Nevada Test Site has been developed in accordance with the Federal Facility Agreement and Consent Order that was agreed to by the U.S. Department of Energy, Nevada Operations Office; the State of Nevada Division of Environmental Protection; and the U.S. Department of Defense.

The Fuel Storage Area was used to store fuel and other petroleum products necessary for motorized operations at the historic Camp Desert Rock facility which was operational from 1951 to 1958 at the Nevada Test Site, Nevada. The fuel storage area was dismantled after 1958 (DOE/NV, 1996a).

The conceptual site model for the Fuel Storage Area in the Data Quality Objectives process is summarized as follows:

- Contaminants of potential concern, if present, are associated with the storage of petroleum products at the site that may have been released into the soil from accidental spills.

- Contaminants of potential concern are limited vertically to less than 3 meters (10 feet) and laterally within the bermed area.

Impacts to groundwater from contaminants of potential concern are unlikely because the depth to groundwater is extensive (greater than 240 meters [800 feet]) (Winograd and Thordarson, 1975; LaCamera and Westenburg, 1994) and the environmental conditions at the site (i.e., arid climate, high evaporation) are not conducive to downward migration of contaminants.

Twelve sampling locations for this site are statistically based in order to increase the level of confidence of finding any contaminants, if present. In addition to the 12 statistically based sample locations, six biased sample locations will also be selected in areas where contaminants may have been concentrated. Total petroleum hydrocarbons are considered to be the primary contaminant or the indicator parameter for this site. Field screening will be performed at all sample locations for volatile organic compounds and total petroleum hydrocarbons. The field screening results will be used to determine if sampling will continue or stop at a particular sample location. Soil samples will be collected using a direct push method at 1 foot and 2 feet below ground surface. At some sample 
locations, soil samples will be collected at 4 feet below ground surface. During the field investigation other sample locations may be selected at the discretion of the Site Supervisor.

All wastes generated during this investigation will be managed under applicable federal, state, and local regulations and requirements. Details of the waste management plan for the Fuel Storage Area are included in Section 5.0 of the Corrective Action Investigation Plan. Investigation-derived waste soil will be returned to the site sample locations pending the corrective action decision.

Under the Federal Facility Consent and Agreement Order, the Corrective Action Investigation Plan for the Fuel Storage Area will be submitted to the Nevada Division of Environmental Protection by February 1, 1999. The field investigation will be conducted following Nevada Division of Environmental Protection's approval of the Corrective Action Investigation Plan. The results of the field investigation will be used to support an evaluation of corrective action alternatives in the Corrective Action Decision Document. 


\subsection{Introduction}

This Corrective Action Investigation Plan (CAIP) has been developed in accordance with the Federal Facility Agreement and Consent Order (FFACO) that was agreed to by the U.S. Department of Energy, Nevada Operations Office (DOE/NV); the State of Nevada Division of Environmental Protection (NDEP); and the U.S. Department of Defense (FFACO, 1996). The CAIP is a document that provides or references all of the specific information for investigation activities associated with Corrective Action Units (CAUs) or Corrective Action Sites (CASs). According to the FFACO (1996), CASs are sites potentially requiring corrective action(s) and may include solid waste management units or individual disposal or release sites. A CAU consists of one or more CASs grouped together based on geography, technical similarity, or agency responsibility for the purpose of determining corrective actions.

This CAIP contains the environmental sample collection objectives and the criteria for conducting site investigation activities at the CAU 321 Area 22 Weather Station Fuel Storage, CAS 22-99-05 Fuel Storage Area. For purposes of this discussion, this site will be referred to as either CAU 321 or the Fuel Storage Area. The Fuel Storage Area is located in Area 22 of the Nevada Test Site (NTS). The NTS is approximately 105 kilometers (km) (65 miles [mi]) northwest of Las Vegas, Nevada (Figure 1-1) (DOE/NV, 1996a). The Fuel Storage Area (Figure 1-2) was used to store fuel and other petroleum products necessary for motorized operations at the historic Camp Desert Rock facility which was operational from 1951 to 1958 at the Nevada Test Site, Nevada. The site was dismantled after 1958 (DOE/NV, 1996a).

\subsection{Purpose}

This CAIP presents a plan to investigate the Fuel Storage Area. The purpose of the corrective action investigation described in this CAIP is to:

- Determine location of any fuel spills that may have occurred at the site.

- Identify the presence and nature of contaminants of potential concern (COPCs). 


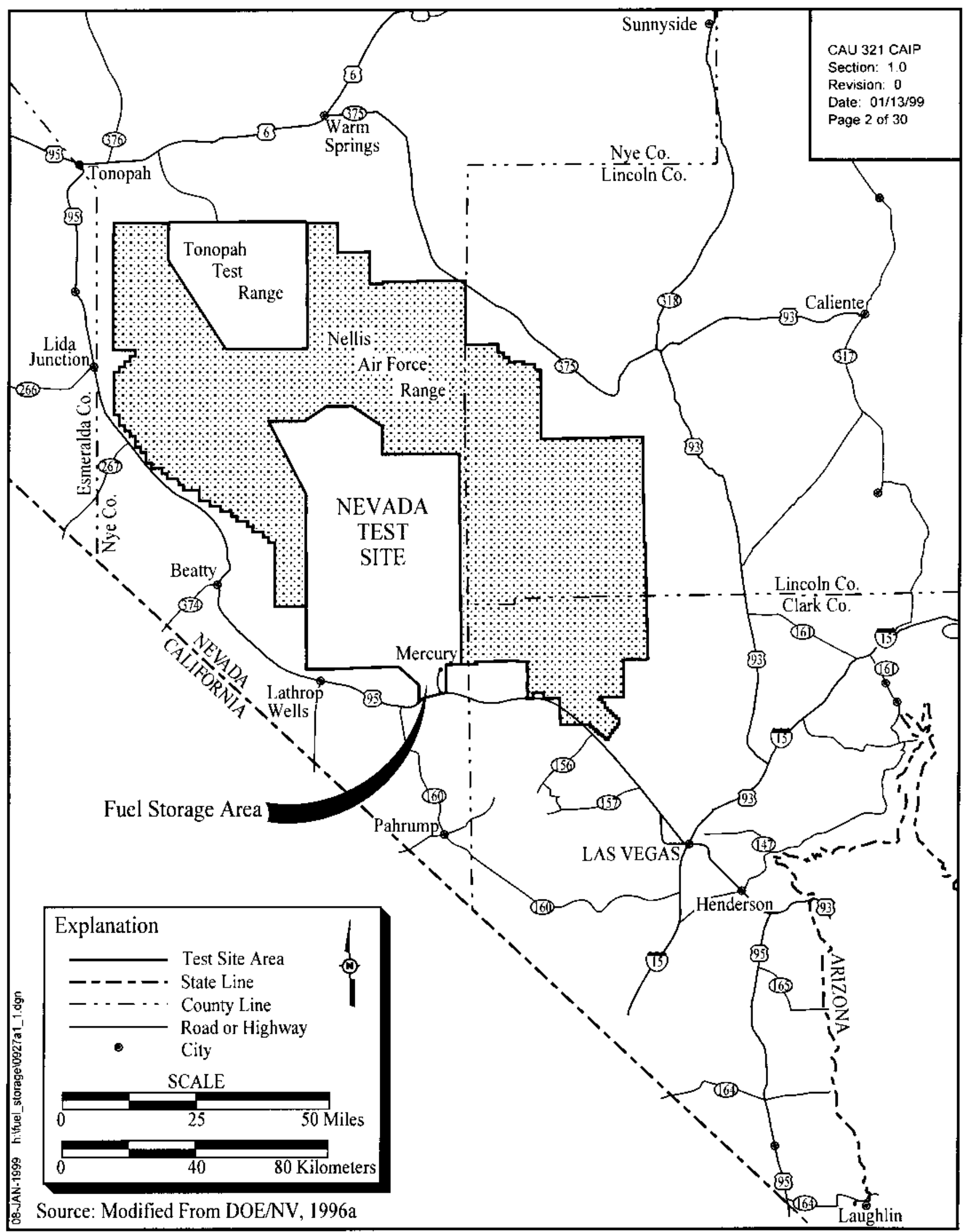

Figure 1-1

Nevada Test Site and CAU 321 Fuel Storage Area Location Map, Nevada 


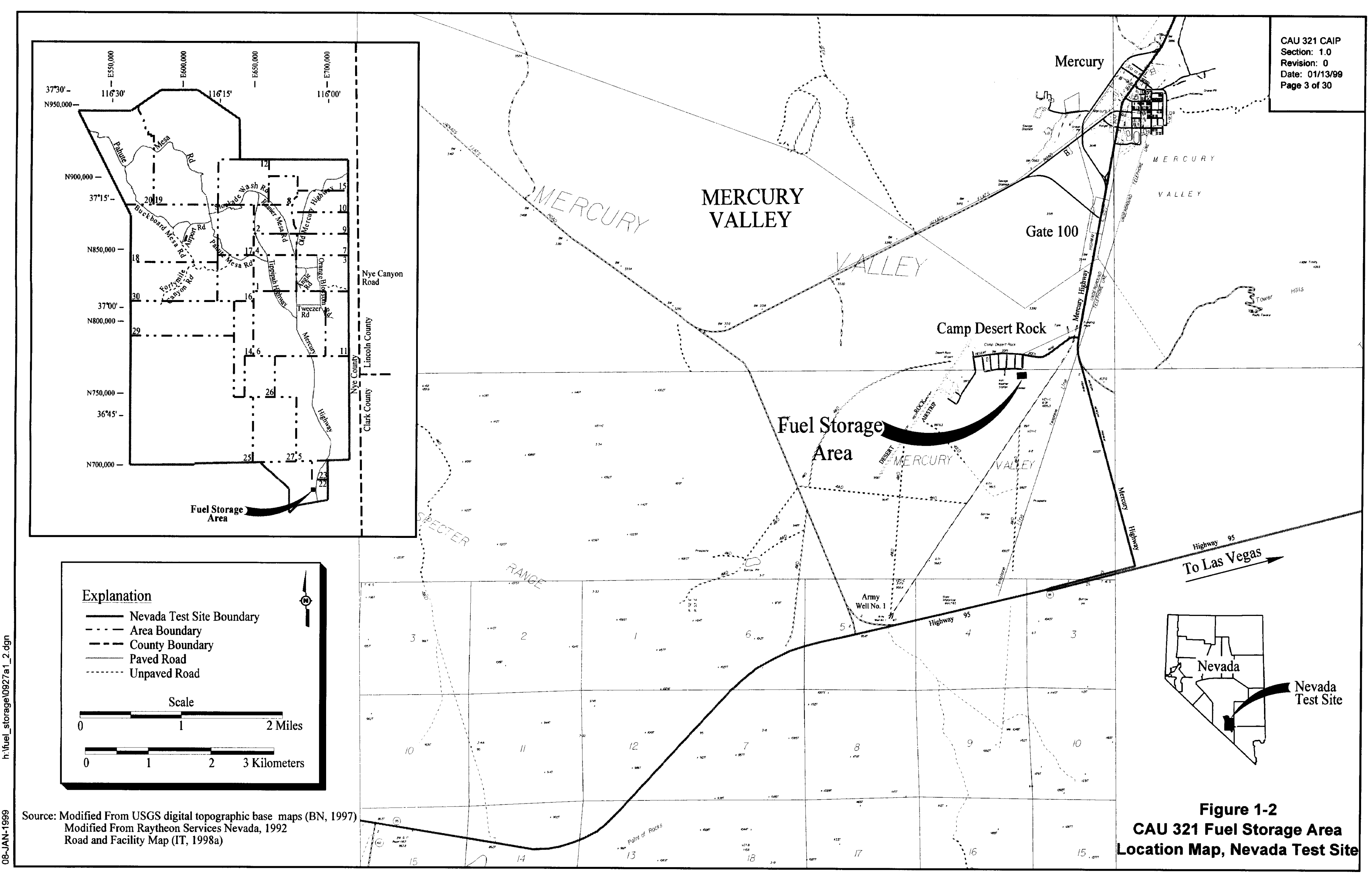


- Determine the vertical and lateral extent of COPCs.

- Provide sufficient information and data to determine the need for and develop and evaluate appropriate corrective actions for the Fuel Storage Area.

This CAIP was developed using the U.S. Environmental Protection Agency's (EPA) Data Quality Objectives (DQOs) (EPA, 1994b) process to clearly define the goals for collecting environmental data, to determine data uses, and to design a data collection program that will satisfy these goals and uses. A DQO scoping meeting was held prior to preparation of this plan; a brief summary of the DQOs is presented in Section 3.4. A more detailed summary of the DQO process and results is included in Appendix A.

\subsection{Scope}

The scope of this CAIP is to resolve the problem statement identified during the DQO process, which states that hydrocarbons and potentially hazardous wastes may have been discharged to the Fuel Storage Area. Existing information regarding the nature and extent of contamination is insufficient to evaluate and select preferred corrective actions for this site (see Appendix A). Therefore, the scope of the corrective action investigation for the Fuel Storage Area includes the following tasks:

- Determine the locations of any fuel spills at the Fuel Storage Area

- Sampling locations will be statistically based to increase the level of certainty of finding COPCs and to optimize the number of sample locations. Additional biased sample locations will also be selected in likely worst-case areas.

- Collect soil samples using a direct push method (such as the GeoProbe ${ }^{\circledR}$ ).

- Utilize field-screening methods to determine the presence of COPCs and guide the investigation.

- $\quad$ Determine the nature and extent of COPCs

- Identify the types and concentrations of COPCs through field and laboratory analytical methods and techniques.

- If COPCs above field-screening or preliminary action levels are found, then determine the lateral and vertical extent through additional sampling as needed. 


\subsection{CAIP Contents}

Section 1.0 of this CAIP provides an introduction to this project, including the purpose and scope for this corrective action investigation. The remainder of the document details the investigation strategy and complies with the following required FFACO (1996) elements:

- Management

- Technical aspects

- Quality assurance

- Health and safety

- Public involvement

- Field sampling

- Waste management

The managerial aspects of this project are discussed in the DOE/NV Project Management Plan (DOE/NV, 1994a) and the site-specific Field Management Plan that will be developed prior to field activities. The technical aspects of this CAIP are contained in Section 3.0 and Section 4.0 of this document and in the DQO summary presented in Appendix A. General field and laboratory quality assurance and quality control (QA/QC) issues, including collection of QC samples, are presented in the Industrial Sites Quality Assurance Project Plan (QAPP) (DOE/NV, 1996c); the methods for field QA/QC are discussed in approved procedures. The general health and safety aspects of this project are discussed in the Environmental Restoration Project Health and Safety Plan (HASP) (DOE/NV, 1996b) and will also be supplemented with a site-specific HASP (SSHASP) written and approved prior to the start of field work. No CAU-specific public involvement activities are planned at this time; however, an overview of public involvement is documented in the "Public Involvement Plan" in Appendix V of the FFACO (1996). Field sampling activities are discussed in Section 4.0 of this CAIP; waste management issues are discussed in Section 5.0. The project schedule and records availability information for this CAIP are discussed in Section 6.0, and Section 7.0 provides a list of project references. 


\subsection{Facility Description}

The NTS Area 22 Camp Desert Rock facility was operated by the Sixth Army installation from 1951 to 1958 and then dismantled after 1958 (DOE/NV, 1996a). Camp Desert Rock was used as a staging area for accommodating up to 6,000 troops from all four military services involved in training exercises associated with nuclear weapons testing by the U.S. Atomic Energy Commission (the U.S. Atomic Energy Commission eventually became the U.S. Department of Energy [DOE]) on the Nevada Proving Ground (later known as the Nevada Test Site). The Camp Desert Rock facility included an airstrip; a sewer system; and approximately 100 semipermanent buildings and 500 tents for housing, administration, storage, and other uses. Numerous above-ground fuel storage tanks were located throughout the facility, in addition to three 10,000-gallon gasoline underground storage tanks.

\subsection{Physical Setting}

Surficial soils at the Fuel Storage Area are alluvial and consist of poorly sorted sand, gravel, and cobbles. Vegetation at the site is well established and is consistent with the vegetation in adjacent areas. The general topography of the area slopes at a relatively slight gradient to the south and southwest with surface drainage flowing in the same direction. Average annual precipitation for valleys in the South-Central Great Basin ranges from 7 to 13 centimeters $(\mathrm{cm})$ (3 to 6 inches [in.]) (Winograd and Thordarson, 1975). Annual evapotranspiration rates have not been precisely determined for plant communities and bare soil conditions for most of the Death Valley Region (D’Agnese et al., 1997). The arid environment is characterized by low humidity, high temperatures, abundant sunshine, and light to moderate winds that can produce very high potential evaporation rates (D’Agnese et al., 1997). The potential annual evaporation from lake and reservoir surfaces was estimated by Meyers (1962) to range from 60 to $82 \mathrm{in.} \mathrm{(Winograd} \mathrm{and} \mathrm{Thordarson,} \mathrm{1975).} \mathrm{At} \mathrm{the}$ CAU 321 site, there is not a sufficient driving force that would aid in mobilizing COPCs beyond the shallow depths 0 to 2 meters $(\mathrm{m})$ (0 to 6 feet [ft]) due to the arid environment.

Depth to ground water is estimated at 240 to $340 \mathrm{~m}$ (800 to $1,100 \mathrm{ft}$ ) below ground surface (bgs) (LaCamera and Westenberg, 1994). The distance to the nearest water-supply well, Army Well 1, is approximately $4.4 \mathrm{~km}$ (2.75 mi) southwest of the Fuel Storage Area (BN, 1997). Army Well 1 is 
used as a back up water supply for Mercury, Nevada. The groundwater flow direction is generally to the southwest (Laczniak et al., 1996).

\subsection{Operational History}

The Fuel Storage Area is shown as a petroleum, oil, and lubricants dump on basic information maps for the Camp Desert Rock facility (USACE, 1958). It is assumed that this site was used for storage and the word "dump," as identified on the map, actually refers to a storage area for fuel (for example, ordnance dump actually refers to ordnance storage area). The Fuel Storage Area was identified as a potential oil spill site in Nevada Test Site, Inventory of Inactive and Abandoned Facilities and Waste Sites, April 1991, Volume 5 (REECo, 1991). A 1955 aerial photograph, SC051098 (RSL, 1955), shows two rectangular tanks and other items stored within the bermed Fuel Storage Area (Figure 2-1). Areas of an unknown ponded liquid are evident on this photograph. However, the site currently has only one relatively small area where slightly discolored soil has been observed. Otherwise, there is no visible staining, odors, or vegetative stress observed within the Fuel Storage Area. Two preliminary surface-soil samples were collected from within the bermed area; no COPCs were identified from these samples (see Section 2.5).

\subsection{Waste Inventory}

No information has been identified that would provide evidence of the types and/or volumes of products and/or waste inventory stored at the Fuel Storage Area. Basic information maps (USACE, 1958) and a 1955 aerial photograph (RSL, 1955) indicate the site was most likely used to store petroleum, oil, and lubricants for the Camp Desert Rock facility (see Section 2.0).

\subsection{Release Information}

No documented evidence exists regarding any COPC release(s), if any occurred. Any release(s) are assumed to be associated with the accidental spillage of petroleum products. Also, more than 40 years have passed since the Fuel Storage Area was operational; if any fuel spills did occur, then natural biological processes most likely would have degraded any total petroleum hydrocarbons (TPH) and/or associated COPCs. 


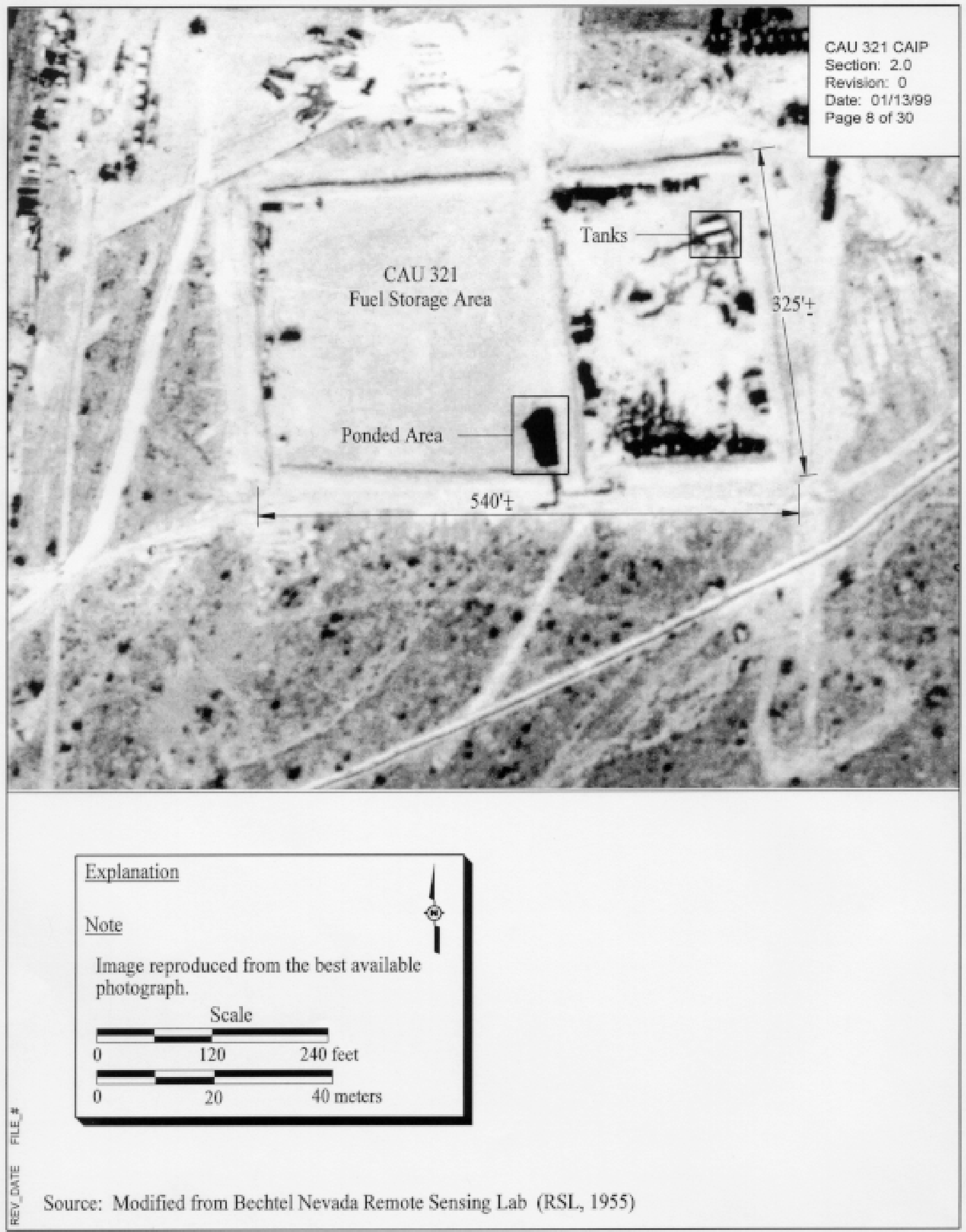

Figure 2-1

1955 Aerial Photograph of the

CAU 321 Fuel Storage Area 


\subsection{Investigative Background}

Two preliminary soil samples were collected by IT Corporation, Las Vegas (ITLV) personnel and analyzed from CAU 321 on August 16, 1997 (Bordelois, 1998). The intent of the preliminary sampling was to collect soil considered most likely to be contaminated to determine the identity of COPCs. The samples were analyzed for total volatile organic compounds (VOCs), total semivolatile organic compounds (SVOCs), diesel/waste oil-range TPH, Resource Conservation and Recovery Act (RCRA) metals, total polychlorinated biphenyls (PCBs), gross alpha and beta emitters, and gamma emitting isotopes for these two samples. Arsenic was the only COPC identified above the industrial preliminary remediation goals (PRGs) (EPA, 1998). The PRG for arsenic is 3.0 milligrams per kilogram $(\mathrm{mg} / \mathrm{kg})$. However, the arsenic concentrations of $7.4 \mathrm{mg} / \mathrm{kg}$ and $6.1 \mathrm{mg} / \mathrm{kg}$ for samples ERS00017 and ERS00018, respectively, are not unusual for the State of Nevada (Shacklette and Boerngen, 1984) and arsenic is not considered to be a COPC for the corrective action investigation.

In addition to the two soil samples collected, two geophysical surveys were conducted by Bechtel Nevada (BN) on September 22 and September 29, 1998. The geophysical surveys were conducted to determine if any underground storage tanks or pipes were present at the Fuel Storage Area. The results from both surveys indicate that no underground tanks or pipes are present at the site (BN, 1998).

Site investigation activities associated with CAU 321 have been identified and documented in the Final Environmental Impact Statement for the Nevada Test Site and Off-Site Locations in the State of Nevada (DOE/NV, 1996a). In accordance with the DOE/NV National Environmental Policy Act (NEPA) compliance program, a NEPA checklist shall be completed prior to commencement of site investigation activities at CAU 321. This checklist compels DOE/NV projects to evaluate their proposed project against a list of several potential environmental impacts which include, but are not limited to, air quality, chemical use, waste generation, noise level, and land use. Completion of the checklist results in a determination of the appropriate level of NEPA documentation by the DOE/NV NEPA Compliance Officer. 


\subsection{Objectives}

The DQOs are qualitative and quantitative statements that specify the quality of the data required to support potential corrective action(s) for the Fuel Storage Area. The DQOs were developed to clearly define the purposes for which environmental data will be used and to design a data collection program that will satisfy these purposes. The formulation of a conceptual site model is an aid to the development of DQOs for the site.

\subsection{Conceptual Site Model}

The conceptual site model for the Fuel Storage Area in the DQO process is presented in Appendix A and is summarized as follows:

- $\quad$ COPCs, if present, are associated with the storage of petroleum products at the site that may have been released into the soil from accidental spills (Table 3-1).

- COPCs are limited vertically to less than $3 \mathrm{~m}(10 \mathrm{ft})$ and laterally within the bermed area.

Groundwater impact is unlikely because the depth to groundwater is extensive (greater than $240 \mathrm{~m}$ [800 ft]) (Winograd and Thordarson, 1975; LaCamera and Westenburg, 1994), and the environmental conditions at the site (i.e., arid climate, high evaporation) are not conducive to downward migration of COPCs.

\subsection{Contaminants of Potential Concern}

The following list of COPCs is based on process knowledge that the site was used for storing petroleum products:

- TPH-diesel and waste oil range

- VOCs

- $\mathrm{SVOCS}$

- Lead

- Radionuclides (not expected, but considered for precautionary purposes only)

Total petroleum hydrocarbons are considered to be the primary COPCs. If TPH is present, then other contamination may be also be present including VOCs, SVOCs, and lead (because of the potential for 
Table 3-1

Laboratory Analytical Requirements for CAU 321 Fuel Storage Area

\begin{tabular}{|c|c|c|c|c|c|}
\hline Analyte & Medium & $\begin{array}{l}\text { Analytical } \\
\text { Method }\end{array}$ & $\begin{array}{c}\text { Minimum Reporting } \\
\text { Limit }\end{array}$ & $\begin{array}{c}\text { Precision } \\
\text { (RPD) }^{\mathrm{a}}\end{array}$ & $\begin{array}{c}\text { Accuracy } \\
(\% R)^{b}\end{array}$ \\
\hline \multirow{2}{*}{ Total VOCs } & Water & \multirow{2}{*}{$8260 \mathrm{~B}^{\mathrm{c}}$} & \multirow{2}{*}{$\begin{array}{c}\text { Analyte-specific } \\
\text { estimated quantitation } \\
\text { limits }^{d}\end{array}$} & $14^{\mathrm{e}}$ & $61-145^{\mathrm{e}}$ \\
\hline & Soil & & & $24^{\mathrm{e}}$ & $59-172^{\mathrm{e}}$ \\
\hline \multirow{2}{*}{ Total SVOCs } & Water & \multirow{2}{*}{$8270 C^{c}$} & \multirow{2}{*}{$\begin{array}{c}\text { Analyte-specific } \\
\text { estimated quantitation } \\
\text { limits }^{d}\end{array}$} & $50^{\mathrm{e}}$ & $9-127^{e}$ \\
\hline & Soil & & & $50^{e}$ & $11-142^{\mathrm{e}}$ \\
\hline \multirow{4}{*}{ TPH } & Water (gasoline) & \multirow{4}{*}{ 8015B modified ${ }^{c}$} & $0.1 \mathrm{mg} / \mathrm{L}^{f}$ & \multirow{4}{*}{ Lab-specific $^{g}$} & \multirow{4}{*}{ Lab-specific ${ }^{g}$} \\
\hline & $\begin{array}{l}\text { Water (diesel range } \\
\text { organics including oil) }\end{array}$ & & $0.5 \mathrm{mg} / \mathrm{L}^{\mathrm{f}}$ & & \\
\hline & Soil (gasoline) & & $0.5 \mathrm{mg} / \mathrm{kg}^{\dagger}$ & & \\
\hline & $\begin{array}{c}\text { Soil (diesel range } \\
\text { organics including oil) }\end{array}$ & & $25 \mathrm{mg} / \mathrm{kg}^{f}$ & & \\
\hline \multirow{2}{*}{ Total Lead } & Water & $6010 B^{c}$ & $3 \mu \mathrm{g} / \mathrm{L}^{\mathrm{f}, \mathrm{h}}$ & $20^{\mathrm{h}}$ & $75-125^{h}$ \\
\hline & Soil & $6010 B^{c}$ & $0.3 \mathrm{mg} / \mathrm{kg}^{\mathrm{f}, \mathrm{h}}$ & $20^{h}$ & $75-125^{h}$ \\
\hline TCLP' Lead & Soil or Water & $1311^{\mathrm{j}} / 6010 \mathrm{~B}^{\mathrm{c}}$ & $0.03 \mathrm{mg} / \mathrm{L}^{\mathrm{f}, \mathrm{h}}$ & $20^{\mathrm{h}}$ & $75-125^{\mathrm{h}}$ \\
\hline \multirow[b]{2}{*}{$\begin{array}{l}\text { Gamma-Emitting } \\
\text { Radionuclides }\end{array}$} & Water & EPA $901.1^{\mathrm{k}}$ & Isotope specific & 20 & \multirow{2}{*}{$\begin{array}{c}\text { Tracer yield } \\
30 \text { - } 105 \\
\text { Laboratory } \\
\text { control sample } \\
\text { yield } \\
80-120\end{array}$} \\
\hline & Soil & HASL $300^{\mathrm{m}}$ & Isotope specific & 35 & \\
\hline
\end{tabular}

${ }^{\mathrm{a}} \mathrm{RPD}$ is used to Calculate Precision

Precision is estimated from the relative percent difference of the concentrations measured for the matrix spike and matrix spike duplicate analyses of unspiked field samples, or field duplicates of unspiked samples. It is calculated by: $R P D=100 \times\left\{\left(\left|C_{1}-C_{2}\right|\right) /\left[\left(C_{1}+C_{2}\right) / 2\right]\right\}$, where $C_{1}=C_{0}$ centration of the analyte in the first sample aliquot, $\mathrm{C}_{2}=$ Concentration of the analyte in the second sample aliquot.

$b_{\%} R$ is used to Calculate Accuracy

Accuracy is assessed from the recovery of analytes spiked into a blank or sample matrix of interest, or from the recovery of surrogate compounds spiked into each sample. The recovery of each spiked analyte is calculated by: $\% R=100 \times\left(\mathrm{C}_{s}-\mathrm{C}_{\mathrm{u}} / \mathrm{C}_{\mathrm{n}}\right)$, where $\mathrm{C}_{\mathrm{s}}=\mathrm{Concentration}_{\mathrm{s}}$ of the analyte in the spiked

sample, $C_{u}=$ Concentration of the analyte in the unspiked sample, $C_{n}=$ Concentration increase that should result from spiking the sample

${ }^{\mathrm{c}}$ Test Methods for Evaluating Solid Waste, 3rd Edition, Parts 1-4, SW-846 (EPA, 1996)

${ }^{\mathrm{d}}$ Estimated Quantitation Limit as given in Method SW-846, U.S. EPA (EPA, 1996)

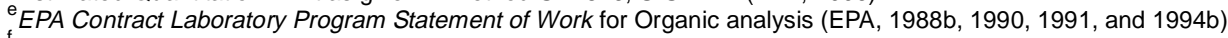

I Industrial Sites Quality Assurance Project Plan (DOE/NV, 1996c)

${ }^{\mathrm{g}}$ In-House Generated RPD and \%R Performance Criteria

It is necessary for laboratories to develop in-house performance criteria and compare them to those in the methods. The laboratory begins by analyzing $15-20$ samples of each matrix and calculating the mean \%R for each analyte. The standard deviation (SD) of each \%R is then calculated, and the warning and control limits for each analyte are established at $\pm 2 \mathrm{SD}$ and $\pm 3 \mathrm{SD}$ from the mean, respectively. If the warning limit is exceeded during the analysis of any sample delivery group (SDG), the laboratory institutes corrective action to bring the analytical system back into control. If the control limit is exceeded, the sample results for that SDG are considered unacceptable. These limits are reviewed after every 20-30 field samples of the same matrix and are updated at least semiannually. The laboratory tracks trends in both performance and control limits by the use of control charts. The laboratory's compliance with these requirements is confirmed as part of an annual laboratory audit. Similar procedures are followed in order to generate acceptance criteria for precision measurements.

hEPA Contract Laboratory Program Statement of Work for Inorganic Analysis (EPA 1988a, 1993, 1994a)

iToxicity Characteristic Leaching Procedure (CFR, 1998a)

j'Test Methods for Evaluating Solid Waste, 3rd Edition, Parts 1-4, SW-846 (EPA, 1992)

${ }^{k}$ Prescribed Procedures for Measurements of Radioactivity in Drinking Water (EPA, 1980) or equivalent method

The mean isotopic concentration plus two standard deviations of the mean based upon sample readings taken from background locations in the vicinity of the site

${ }^{m}$ Environmental Measurements Laboratory Procedures Manual (DOE, 1992) or equivalent method

TCLP - Toxicity Characteristic Leaching Procedure

$\mathrm{mg} / \mathrm{kg}$ - Milligrams per kilogram

$\mathrm{mg} / \mathrm{L}$ - Milligrams per liter

$\mu \mathrm{g} / \mathrm{L}$ - Micrograms per liter 
leaded gasoline). Radiological emitters are not considered likely contaminants, but field surveys of the samples will be conducted for alpha/beta emitters during the investigation. If field screening levels for alpha and beta emitters (see Section 3.3.1) are exceeded, then radiological samples, including background samples, will be collected. Otherwise samples for radiological analyses will not be collected.

\subsection{Preliminary Action Levels}

Preliminary field screening levels (FSLs) for on-site field screening methods and preliminary action levels (PALs) for off-site laboratory analytical methods will be used to determine the presence of contamination.

\subsubsection{Field Screening Levels}

The following field screening levels will be used for on-site field screening/surveying methods:

- Volatile organic compounds headspace is 20 parts per million (ppm) or 2.5 times background, whichever is greater, using a photoionization detector.

- Total petroleum hydrocarbons is 100 ppm using the Hanby kit.

- Alpha/beta radionuclides are set at the mean surficial-background level from 20 locations plus background activity level plus two times the standard deviation of the mean surficial-background activity level.

Concentrations exceeding FSLs will indicate potential contamination at that particular sample location. This information will be documented, and the investigation will be continued to delineate the extent of the contamination as necessary. Additionally, these field screening data will be used to select discretionary samples to be submitted to the laboratory. 


\subsubsection{Chemical Preliminary Action Levels}

Off-site laboratory analytical results will be compared to the following PALs to evaluate the need for possible corrective actions:

- NDEP Corrective Action Regulations (NAC, 1997); for purposes of this investigation, the risk-based Industrial Soil PRGs for EPA Region IX will be used as the PALs.

- $\quad$ The TPH concentration of $100 \mathrm{mg} / \mathrm{kg}$ per the Nevada Administrative Code (NAC) 445A.2272 (NAC, 1997)

Laboratory results will be compared to PALs in the Corrective Action Decision Document (CADD). Laboratory results above PALs indicate the presence of COPCs at levels that may require corrective action. The evaluation of potential corrective actions and the justification for a preferred action will be included in the CADD based on the results of this field investigation.

\subsubsection{Radiological Preliminary Action Levels}

Radiological contamination is not expected at this site. However, as a precautionary measure alpha/beta radiological field surveys will be conducted as specified in Section 3.3.1. If alpha/beta field survey results exceed the field screening levels, then gamma spectroscopy will be conducted at an off-site laboratory. The preliminary action levels for gamma spectroscopy are isotope specific and will be based on the mean isotopic concentration plus two standard deviations of the mean based on sample readings taken from background samples collected at locations within the vicinity of the CAU 321 Site. These sample background locations may include sample readings from Area 23.

\subsection{DQO Process Discussion}

Details of the DQO process are presented in Appendix A. During the DQO discussions for the Fuel Storage Area, a statistically based sampling approach was identified for this site. Contamination is not expected to occur deeper than $3 \mathrm{~m}$ (10 ft) bgs and the investigation will utilize a direct-push method to conduct soil sampling. The COPCs, analytical methods, and reporting limits prescribed through the DQO process are provided in Table 3-1. The precision and accuracy requirements are those stated in the latest revision of the individual EPA SW-846 methods (EPA, 1996).

Representativeness for the investigation and resulting data will be evaluated by confirming or refuting the conceptual model. 


\subsection{Field Investigation}

This section of the CAIP contains the sampling approach for investigating the Fuel Storage Area. All sampling activities will be conducted in compliance with the Industrial Sites QAPP (DOE/NV, 1996c) and other applicable, approved procedures. Quality assurance and quality control requirements for field and laboratory environmental sampling are also contained in the Industrial Sites QAPP (DOE/NV, 1996c) and in Table 3-1. The general sampling strategy will focus on answering the problem question, "Is the site contaminated?" Sampling locations for this site will be statistically based to increase the level of confidence of finding any COPCs, if present. Additional biased sample locations will also be selected at potential worst-case areas. Field screening techniques will be the primary investigation tool for determining if COPCs are present. Subsequent laboratory analyses will also be conducted for confirmation and verification of the field screening results.

Field activities will be performed in accordance with an approved SSHASP which concurs with the DOE Integrated Safety Management System (DOE, 1996). Safety, health, and protection of the environment take precedence over expediency and shortcuts. Site personnel will take every reasonable step to reduce the possibility of injury, illness, or accidents, and to protect the environment during all project activities. The following safety issues will be included and discussed in the SSHASP:

- Expected site hazards

- Personnel training to mitigate expected site hazards

- Engineering controls to mitigate site hazards, when feasible

- Work controls to reduce site hazards

- Monitoring will be performed for VOCs and radiological surveying will be conducted for only alpha/beta emitters in order to minimize and/or control personnel exposures. Exposures will be kept as low as reasonably achievable.

- Emergency communication procedures 


\subsection{Sampling Strategy}

The sampling investigation for CAU 321 is described in the following sections.

\subsubsection{Sampling Locations}

Statistically based and biased sampling locations (Figure 4-1) will be selected for soil sampling at the Fuel Storage Area as described in Appendix A (Sections A.4.0, A.5.0, and A.6.0). Statistical sampling is appropriate because there is no conclusive evidence of a specific point source (i.e., spill, release, or disposal point). However, additional biased sampling will be conducted at areas where potential ponding may have occurred or where dark areas are shown in an 1955 aerial photograph of the Camp Desert Rock facility (RSL, 1955) and at a slightly discolored area. The confidence levels and sampling errors were agreed to by the DOE/NV and the NDEP. The proposed confidence levels and tolerable errors in the estimation of the sample mean are discussed in the following text.

\subsubsection{Field Screening Confidence Levels for the Hanby Method}

The primary COPC or the indicator parameter for the Fuel Storage Area is TPH. The TPH field screening results will be used to determine if sampling should continue or stop at each sample location. For this investigation, Hanby kits will be used for the TPH field screening. The Hanby TPH detection limits range from $<1 \mathrm{ppm}$ to $>1,000 \mathrm{ppm}$. The manufacturer of the Hanby kit claims a coefficient of variation (CV) of 20 percent for soil analyses (Hanby, 1998). For this investigation the $\mathrm{CV}$ will be increased from 20 to 50 percent (i.e., the assumption that the Hanby method is not as reproducible as the manufacturer claims) and a greater number of samples will be field screened to increase the level of confidence. The relative error in the mean that will be tolerated is 30 percent, which is considered acceptable (EPA, 1989) for a preliminary site investigation. Because of the use of a large standard deviation (poor reproducibility) of the field screening method and the fact that a significant relative error in the mean, a high confidence limit of 95 percent will be used for the preliminary investigation. Inputting these parameters into standard statistical equations for calculating required numbers of samples results in 12 samples from each sampling interval (or stratum) to be field-screened. In addition to the 12 statistically based sample locations, approximately 6 biased sample locations have been selected at areas where ponding occurred or that have the highest likelihood of being contaminated. During the field investigation other sample locations may be selected at the discretion of the Site Supervisor. 


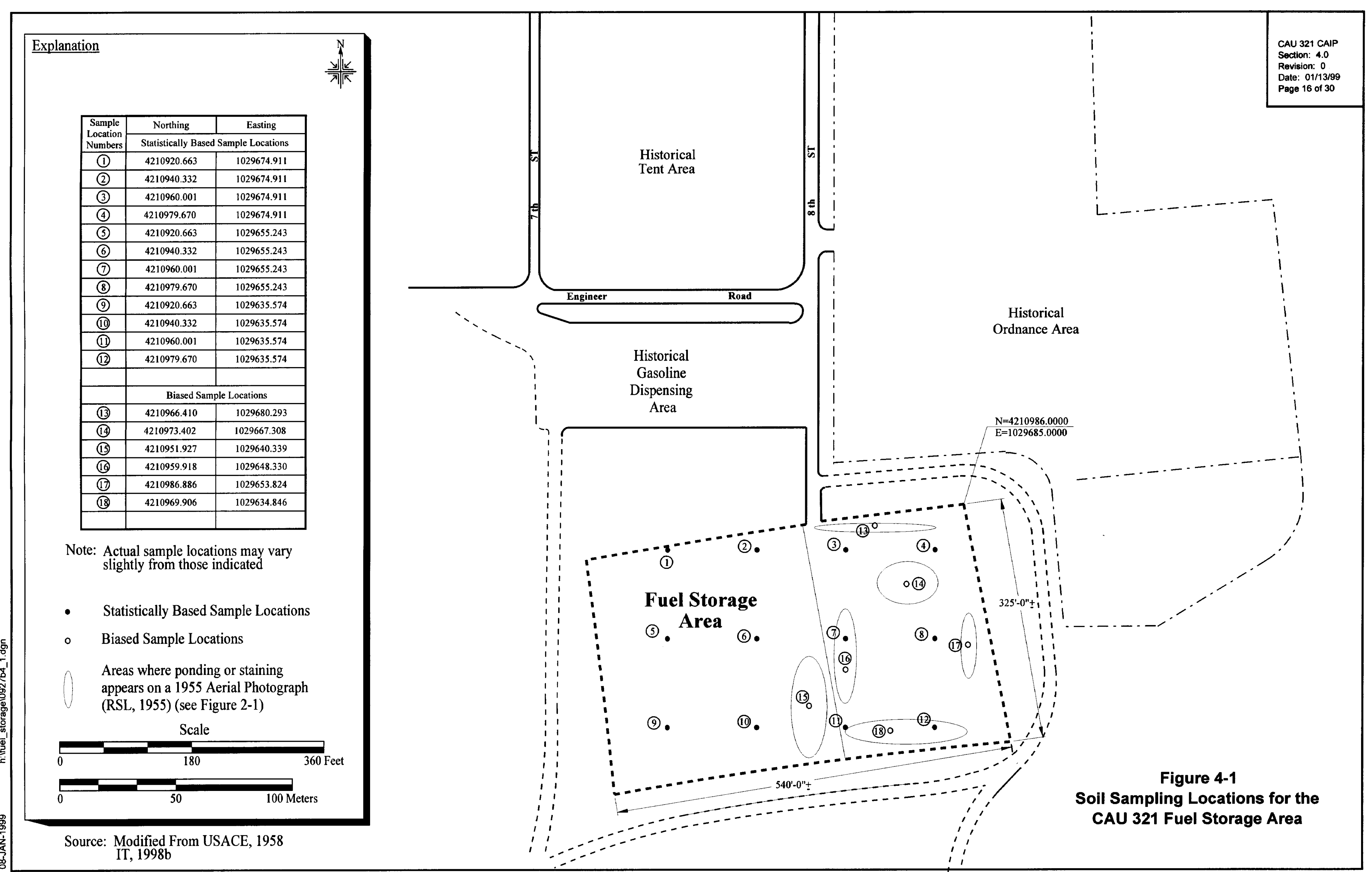




\subsubsection{Nondetect-Field-Screening Samples and Laboratory Confidence Levels}

The reproducibility of the laboratory method for hydrocarbons (SW-846 8015 modified method) is expected to be significantly better than that of the field screening method (described in the previous section); a 20 percent CV for soil analyses by the SW-846 8015 modified method is assumed. A tolerance of no more than 10 percent relative error in the mean will be required, which is considered acceptable for planned removal or remedial response operations (EPA, 1989). A confidence limit of 95 percent will be used for the laboratory analyses conducted for this investigation. Inputting these parameters into standard statistical equations for calculating the required numbers of samples results in 16 samples for which field screening indicates that TPH levels were below FSLs being submitted to the off-site laboratory for confirmation.

\subsubsection{Soil Sampling}

Soil sampling will be conducted with a Geoprobe ${ }^{\circledR}$ or other direct-push method. Soil samples will be collected using a Macrocore ${ }^{\circledR}$ sampling barrel (or similar) with polyvinyl chloride, stainless-steel liners, or other approved liners. The primary soil sampling/field screening intervals will be at $1 \mathrm{ft}$ and $2 \mathrm{ft}$ bgs. However, at three locations, soil samples will be collected from the $4 \mathrm{ft}$ interval (two locations will be selected at random and one selected from an area where ponding may have occurred). The additional $4 \mathrm{ft}$ samples are being evaluated because of the potential for COPCs to have been disturbed and/or degraded nearer the surface ( $1 \mathrm{ft}$ to $2 \mathrm{ft}$ ) but possibly not at the deeper $4 \mathrm{ft}$ interval. If COPCs are detected above the FSLs at a sample location, then sampling will continue at two-foot intervals until two-consecutive nondetect results have been obtained. If COPCs are present at $10 \mathrm{ft}$ and are above the specified FSLs (Section 3.3), then the investigation will stop and be rescoped.

Additional samples may be collected at the discretion of the Site Supervisor. Step-out sampling may also be conducted at no more than a 3:1 ratio (i.e., three-foot laterally from the sampling location per one-foot vertical depth where COPCs are detected above action levels). Additional sampling or step-out sampling may be necessary if:

- Sample analytical results are inadequate for preparing a CADD.

- Lateral and vertical extent of contamination needs to be further delineated. 


\subsubsection{Field Screening and Field Surveys}

Page 18 of 30

Field screening is considered an important part of the investigation for determining if COPCs are present and will be conducted at all sample locations. Field screening confidence levels are discussed in Section 4.1.1.1. Total petroleum hydrocarbons will be screened for using the Hanby kit and VOCs will be field screened for by using a photoionization detector. Field surveys for alpha/beta radiological emitters will be conducted with an Electra alpha/beta scintillator (or equivalent).

Field-screening data will serve three purposes. First, these data will provide semiquantitative measurement of the soil conditions. Second, these data will provide a mechanism for guiding the investigation. Third, these data will be used to aid in the selection of samples to be submitted for laboratory analysis. No field screening will be conducted for SVOCs or lead.

\subsubsection{Sample Selection for Laboratory Analyses}

At the CAU 321 Site, if field screening results are below the FSLs, then samples will be archived and some of the samples will be selected at random and sent to the laboratory for analysis. If all field screening results for the samples are less than FSLs, then a minimum of 16 soil samples collected at the 2-ft interval will be sent to the laboratory for analyses. Otherwise, the final number of samples selected for analysis with field screening results less than FSLs will be decided on a daily basis by the Site Supervisor. The confidence interval for laboratory analyses of samples when field screening results are all below FSLs is described in Section 4.1.1.2.

At each sample location where field screening results are above the FSLs, the sample with the highest field screening result will be sent to the laboratory for analyses. Also from this sample location, the first sample of the two-consecutive nondetect samples (see Section 4.1.2) collected below the sample interval with the highest field screening result will be sent to the laboratory for analyses.

Additional samples may be selected and sent to the laboratory for analyses at the discretion of the Site Supervisor. If COPCs are not detected at the site above action levels, then a Corrective Action Decision Document/Closure Report will be prepared. 
When a sample is selected for laboratory analysis, that sample will be analyzed in accordance with the analytes shown in Table 3-1 with the following guidance:

- All samples sent to the laboratory will be analyzed for TPH, VOCs, SVOCs, and total lead.

- The TCLP will be performed on all samples. However, the TCLP extracts will only be analyzed if the total lead results are not sufficient for waste characterization purposes.

- Gamma spectroscopy will only be conducted if the field screening results exceed the FSLs.

\subsection{Sample Collection and Decontamination Procedures}

All samples, including QA/QC samples, will be collected in accordance with Standard Operating Procedures Manual (DOE/NV, 1994c) and the Industrial Sites QAPP (DOE/NV, 1996c). Records will be kept of the soil description, field-screening measurements, and all other relevant data. All pertinent and required sampling information (i.e., date, time, sample interval) will be documented. All samples will be accompanied by the appropriate chain of custody documentation to ensure the defensibility of these data.

All equipment which contacts the soil will be decontaminated between samples in accordance with the DOE/NV Environmental Restoration Division (ERD) Procedure ERD-05-701, "Sampling Equipment Decontamination,” Rev. 0 (DOE/NV, 1994b) to minimize the potential for cross-contamination between samples.

\subsubsection{Quality Control Samples}

Quality control samples will be collected as required by the Industrial Sites QAPP (DOE/NV, 1996c). These samples will include trip blanks, equipment blanks, field blanks, field duplicates, and matrix spike/matrix spike duplicate (MS/MSD) samples. Except for trip blanks, all QC samples will be analyzed for applicable parameters in Table 3-1. Trip blanks will only be analyzed for VOCs. The QC samples will be collected according to the QAPP and approved procedures. Additional QC samples may be submitted at the discretion of the Site Supervisor. 


\subsection{Waste Management}

Management of investigation-derived waste (IDW) will be based on regulatory requirements, field observations, process knowledge, and the results of laboratory analysis of the fuel storage area investigation samples.

There is no process knowledge that indicates that any "listed" hazardous waste was disposed at this site. Therefore, if hazardous waste constituents are present, they will be considered "characteristic" rather than "listed."

Sanitary, low-level, hydrocarbon, hazardous, and mixed waste (if generated) will be managed and disposed of in accordance with DOE Orders, U.S. Department of Transportation (DOT) regulations, RCRA regulations, Nevada Revised Statutes and agreements and permits between the DOE and NDEP.

\subsection{Waste Minimization}

Corrective action investigation activities have been planned to minimize IDW generation.

Decontamination activities will only use as much water as necessary to decontaminate equipment and personnel and at the same time minimize the amount of rinsate generated. Waste, such as disposable sampling equipment, decontamination rinsate, and personal protective equipment (PPE) will be segregated to the greatest extent possible to minimize the generation of any waste.

\subsection{Potential Waste Streams}

Historical records and process knowledge indicate that the Fuel Storage Area was used to store petroleum fuels. The COPCs at this site, if present, would be related to petroleum products (see Section 3.2). Waste generated during the investigation activities will include but is not limited to the following:

- Potentially contaminated disposable sampling equipment (such as plastic, paper, sample containers, aluminum foil, spoons, scoops, and bowls) and PPE

- Decontamination rinsate

- Hanby kit waste (spent solvent, water/soil mixture, and contaminated PPE) 
The waste will be managed in three distinct waste streams; additional segregation will occur within each waste stream based on sample location. Waste will be traceable to its source and to individual samples; this information will be recorded in the waste management logbook. Excess soil may be returned to the sample location and will be addressed through the CADD and corrective action process.

\subsection{Investigation-Derived Waste Management}

Management requirements for sanitary, low-level, hydrocarbon, hazardous, and mixed waste are discussed further in the following sections. Soil and IDW generated by sampling activities will be managed as potentially hazardous waste until laboratory results indicate either the presence or absence of RCRA regulated constituents.

Waste associated with the Hanby kit will be managed as hazardous waste upon generation. Additional waste that is generated is classified as contaminated waste only by virtue of contact with potentially contaminated media. Therefore, direct sampling of the IDW stream will not be required. The data generated as a result of site characterization and process knowledge will be used to assign the appropriate waste type (i.e., sanitary, low-level, hydrocarbon, hazardous, mixed) to the IDW.

\subsubsection{Sanitary Waste}

Sanitary wastes not directly associated with sampling activities typically consist of plastic, food, and paper products. This waste will be contained in plastic bags and will be transported to an approved solid waste management unit.

\subsubsection{Low-Level Radioactive Waste}

Radiological COPCs are not anticipated at the CAU. Radiological controls will not be instituted unless field-surveying results exceed screening levels specified in Section 3.3. If field-surveying levels are exceeded, the waste will be managed as low-level radioactive waste (LLW) pending analytical results. If LLW is generated, it will be managed in accordance with DOE Orders and the requirements of the Nevada Test Site Waste Acceptance Criteria (NTSWAC) (DOE/NV, 1997). Investigation-derived waste such as PPE will be placed in plastic bags marked with the date and associated sampling location and/or sample number. The bags will be placed in drums that meet 
DOT specifications as defined in 49 Code of Federal Regulations (CFR) 172 (CFR, 1998j) and will be properly labeled and locked or fitted with tamper-indicating devices (TIDs). The drums will be staged at a designated Radioactive Materials Area pending disposal.

Low-level waste will be characterized in accordance with the requirements of the NTSWAC and the contractor-specific waste certification program plan and implementing procedures. Characterization will be based on laboratory results, field screening, process knowledge, or a combination thereof.

\subsubsection{Hydrocarbon Waste}

The action level for soil contaminated with hydrocarbons is $100 \mathrm{mg} / \mathrm{kg}$ in the State of Nevada (NAC, 1997). Soils and associated IDW with TPH levels above $100 \mathrm{mg} / \mathrm{kg}$ which contain RCRA regulated constituents below regulatory limits shall be managed as hydrocarbon waste and shall be disposed of in accordance with all applicable regulations in a hydrocarbon landfill.

\subsubsection{Hazardous Waste}

Hazardous waste will be managed in accordance with RCRA and State of Nevada hazardous waste management regulations, interpreted as follows. Suspected hazardous waste will be placed in 55-gallon drums that meet DOT specifications 49 CFR 172 (CFR, 1998j) which will be locked or fitted with TIDs. The IDW containers will comply with 40 CFR 265.1087 (CFR, 1998i) and shall be compatible with the waste (CFR, 1998e). No incompatible waste are expected to be generated; however, if incompatible waste is encountered in the field, it will be managed in accordance with 40 CFR 265.177 (CFR, 1998h) (i.e., shall not be placed in the same container and shall be separated so that in the event of a spill, leak, or release, incompatible wastes shall not contact one another). Drums shall be handled and inspected in accordance with the requirements of 40 CFR 265.173 and 174, respectively (CFR, 1998f; CFR, 1998g).

Hazardous waste will be characterized in accordance with the requirements of 40 CFR 261 (CFR, 1998a). Characterization will be based on analytical results and process knowledge (CFR, 1998b). Drums containing IDW pending characterization will be marked with the words "Hazardous Waste Pending Analysis" until its regulatory status can be determined through interpretation and evaluation of laboratory results. The IDW shall be traceable to its source and/or 
samples considered analogous to the IDW (such as PPE associated with a sample). Traceability shall be maintained by assigning unique waste tracking numbers to each container and by maintaining records that trace the IDW back to the samples. After receipt of analytical results and if hazardous waste is identified, it will be labeled and marked in accordance with the requirements of $40 \mathrm{CFR}$ 262.32 (CFR, 1998c) and State of Nevada requirements.

Hazardous waste management methods including the establishment of satellite accumulation areas or a 90-day hazardous waste accumulation area (HWAA) will be employed to temporarily accumulate IDW pending characterization. These methods will be appropriate for the amount of waste being accumulated and in compliance with applicable State of Nevada and federal requirements.

Suspected hazardous waste temporarily stored in a 90-day HWAA will be accumulated at or near the site of generation in accordance with 40 CFR 262.34 (CFR, 1998d). Prior to or on the ninetieth day of accumulation, hazardous waste will be shipped by a licensed/permitted hazardous waste transporter to a permitted treatment storage and disposal facility. If hazardous waste must remain on-site for longer than 90 days due to unforeseen, temporary, and uncontrollable circumstances, a letter requesting an extension for up to 30 days will be sent to the NDEP in accordance with 40 CFR Part 262.34(b) (CFR, 1998d). A copy of the uniform hazardous waste manifest shall be provided to the State of Nevada.

\subsubsection{Mixed Waste Management}

No mixed waste is expected to be generated at this site. However, if mixed waste is generated, the waste shall be managed in accordance with state and federal hazardous waste regulations as well as DOE requirements for radioactive waste, interpreted as follows.

Where there is a conflict in regulations or requirements, the most stringent shall apply. For example, the 90-day accumulation time limit and weekly inspections per RCRA regulations will be applied to mixed waste even though it is not required for radioactive waste. Conversely, while RCRA does not require documented traceability, the waste acceptance program for low-level radioactive waste does; therefore, traceability shall be documented. In general, mixed waste shall be managed in the same manner as hazardous waste, with added mandatory radioactive waste management program requirements. Suspected mixed waste will be managed in accordance with applicable regulations and 
requirements and will be marked with "Awaiting Analysis" stickers pending characterization and confirmation of the regulatory status. However, mixed waste shall be transported to the NTS transuranic waste storage pad for storage pending treatment or disposal. Mixed waste with hazardous waste constituents below land disposal restrictions may be disposed of at the NTS Area 5 Radioactive Waste Management Site. Mixed waste not meeting land disposal restrictions will remain in Area 5 and require development of a treatment plan under the requirements of the Mutual Consent Order between DOE and the State of Nevada (NDEP, 1995). 


\subsection{Duration and Records Availability}

\subsection{Duration}

The following is a tentative schedule of activities (in calendar days) that will be initiated after the submittal of the Final CAIP for CAU 321 to the NDEP (FFACO deadline of February 1, 1999).

- Day 0: Field work preparation begins.

- Day 30: Field work, including field screening and sampling begins.

- Day 40: Field work is complete and samples have been shipped to the laboratory for analyses.

- Day 150: The quality-assured laboratory analytical sample data is available for review.

- $\quad$ The FFACO deadline for the CADD is November 30, 1999.

\subsection{Records Availability}

This document is available in the DOE public reading rooms located in Las Vegas and Carson City, Nevada, or by contacting the DOE/NV Project Manager. The NDEP maintains the official Administrative Record for all activities conducted under the auspices of the FFACO. 


\subsection{References}

BN, see Bechtel Nevada.

Bechtel Nevada. 1996. “Gamma-Ray Spectrometry Operations,” Bechtel Nevada Analytical Services Laboratory, Local Implementing Directive L-E10.602.PC, Rev. 0, 15 June. Las Vegas, NV.

Bechtel Nevada. 1997. "Point of Rocks Quadrangle Federal Facility Agreement and Consent Order Corrective Action Site," July 1997. Modified from USGS digital topographic maps.

Las Vegas, NV.

Bechtel Nevada. 1998. Letter from D. K. Cowser to J.L. Appenzeller-Wing, subject "Corrective Action Unit 321 Fuel Storage Area Geophysical Survey Results." Discussion of the results of the geophysical surveys conducted on September 22, 1998 and September 29, 1998 at the CAU 321 Fuel Storage Area, October 13. Las Vegas, NV.

Bordelois, B. (IT Corporation). 1998. Memorandum to Ronald Jackson titled "CAU 321, CAS 22-99-05 Sampling Report," March 17. Las Vegas, NV.

CFR, see Code of Federal Regulations.

Code of Federal Regulations. 1998a. 40 CFR 261, "Identification and Listing Of Hazardous Waste." Washington, DC: U.S. Government Printing Office.

Code of Federal Regulations. 1998b. 40 CFR Part 262.11, "Hazardous Waste Determination." Washington, DC: U.S. Government Printing Office.

Code of Federal Regulations. 1998c. 40 CFR 262.32, "Marking." Washington, DC:

U.S. Government Printing Office.

Code of Federal Regulations. 1998d. 40 CFR 262.34, "Accumulation Time." Washington, DC:

U.S. Government Printing Office.

Code of Federal Regulations. 1998e. 40 CFR 265.172, "Compatibility of Waste with Container." Washington, DC: U.S. Government Printing Office.

Code of Federal Regulations. 1998f. 40 CFR 265.173, "Management of Containers."

Washington, DC: U.S. Government Printing Office.

Code of Federal Regulations. 1998g. 40 CFR 265.174, “Inspections.” Washington, DC:

U.S. Government Printing Office. 
Code of Federal Regulations. 1998h. 40 CFR 265.177, "Special Requirements for Incompatible Wastes." Washington, DC: U.S. Government Printing Office.

Code of Federal Regulations. 1998i. 40 CFR 265.1087, "Standards: Containers." Washington, DC: U.S. Government Printing Office.

Code of Federal Regulations. 1998j. 49 CFR 172, "Hazardous Materials Table, Special Provisions, Hazardous Materials Communications, Emergency Response Information, and Training." Washington, DC: U.S. Government Printing Office.

D’Agnese, F.A., C. C. Faunt, A. K. Turner, and M.C. Hill. 1997. Hydrogeologic Evaluation and Numerical Simulation of the Death Valley Regional Ground-Water Flow System, Nevada and California. Denver CO: U.S. Geological Survey.

DOE, see U.S. Department of Energy.

DOE/NV, see U.S. Department of Energy, Nevada Operations Office.

EPA, see U.S. Environmental Protection Agency.

FFACO, see Federal Facility Agreement and Consent Order.

Federal Facility Agreement and Consent Order. 1996. Agreed to by the State of Nevada, the U.S. Department of Energy, and the U.S. Department of Defense.

Hanby, J. 1998. Telephone conversation between John Hanby (Hanby Environmental Laboratory Procedures, Inc.) and Sylvan D. Hersh (ITLV), 17 September. Las Vegas, NV.

IT Corporation. 1998a. Nevada Test Site Road and Facilities Road, and Facility Map modified from Raytheon Services Nevada Road and Facility Map, 1992. Las Vegas, NV.

IT Corporation. 1998b. Memorandum from S. Hersh to J. Herrington titled "Statistical Selections of Sampling Locations for CAU 321 Fuel Storage Area,” 2 November. Las Vegas, NV.

LaCamera, R.J., and C.L. Westenburg. 1994. Selected Ground-Water Data for Yucca Mountain Region, Southern Nevada and Eastern California, Through December 1992. Carson City, NV: U.S. Geological Survey.

Laczniak, R.J., J.C. Cole, D.A. Sawyer, and D.T. Trudeau. 1996. Summary of Hydrogeological Controls on Ground-Water Flow at the Nevada Test Site, Nye County, Nevada, U.S. Geological Survey Water-Resources Investigations Report 96-4109. Denver, CO: U.S. Geological Survey.

Meyers, J.S. 1962. Evaporation from 17 Western States With a Section on Evaporation Rates by T.J. Nordenson, U.S. Geological Survey Professional Paper 272-D. Denver, CO: U.S. Geological Survey. 
NAC, see Nevada Administrative Code.

Nevada Administrative Code. 1997. NAC 445A.2272, "Contamination of Soil: Establishment of Action Levels." Carson City, NV: Nevada Division of Environmental Protection.

NDEP, see Nevada Division of Environmental Protection.

Nevada Division of Environmental Protection. 1995. Mutual Consent Agreement Between the State of Nevada and the U.S. Department of Energy for the Storage of Low-Level Land Disposal Restricted Mixed Waste, 6 June. Carson City, NV.

NRC, see U.S. Nuclear Regulatory Commission.

Raytheon Services Nevada. 1992. "Road and Facility Map, Nevada Test Site," Nevada Test Site All Areas. Las Vegas, NV.

REECo, see Reynolds Electrical and Engineering Company, Inc.

Reynolds Electrical and Engineering Company, Inc. 1991. Nevada Test Site, Inventory of Inactive and Abandoned Facilities and Waste Sites, Volume 5, April. Las Vegas, NV.

RSL, see Remote Sensing Laboratory.

Remote Sensing Laboratory. 1955. Photo of Camp Desert Rock facility, photograph \#SC510958. Nellis Air Force Base, NV: Photo Archive Library.

Shacklette, H.T., and J.G. Boerngen. 1984. Element Concentrations in Soils and Other Surficial Materials of the Conterminous United States, U.S. Geological Survey Professional Paper 1270. Washington, DC: U.S. Government Printing Office.

USACE, see U.S. Army Corps of Engineers.

U.S. Army Corps of Engineers. 1958. "Basic Information Maps for Camp Desert Rock." Barstow, CA.

U.S. Department of Energy. 1992. "Environmental Measurements Laboratory Procedures Manuals," HASL-300, 27th Edition, Vol. 1. New York, NY.

U.S. Department of Energy. 1996. Safety Management System, Policy-P450.4, October 10. Washington, DC.

U.S. Department of Energy, Nevada Operations Office. 1994a. Project Management Plan, Rev. 0. Las Vegas, NV. 
U.S. Department of Energy, Nevada Operations Office. 1994b. Sampling Equipment Decontamination, ERD-05-701, Rev. 0. Las Vegas, NV.

U.S. Department of Energy, Nevada Operations Office. 1994c (as amended). Standard Operating Procedure Manual. Las Vegas, NV: DOE/NV.

U.S. Department of Energy, Nevada Operations Office. 1996a. Final Environmental Impact Statement for the Nevada Test Site and Off-Site Locations in the State of Nevada, DOE/EIS 0243. Las Vegas, NV.

U.S. Department of Energy, Nevada Operations Office. 1996b. Health and Safety Plan, Rev. 2, Environmental Restoration Project. Las Vegas, NV.

U.S. Department of Energy, Nevada Operations Office. 1996c. Industrial Sites Quality Assurance Project Plan, DOE/NV--372. Las Vegas, NV.

U.S. Department of Energy, Nevada Operations Office. 1997. Nevada Test Site Waste Acceptance Criteria, NTSWAC, Rev. 1. Las Vegas, NV.

U.S. Environmental Protection Agency. 1988a. Contract Laboratory Program Statement of Work for Inorganics Analysis, ILMO 3.0. Washington, DC.

U.S. Environmental Protection Agency. 1988b. Contract Laboratory Program Statement of Work for Organic Analysis, 2/88. Washington, DC.

U.S. Environmental Protection Agency. 1989. Soil Sampling Quality Assurance User's Guide, Second Edition, EPA/600/8-89/046. Washington, DC.

U.S. Environmental Protection Agency. 1990. Contract Laboratory Program Statement of Work for Organic Analysis, 3/90. Washington, DC.

U.S. Environmental Protection Agency. 1991. Contract Laboratory Program Statement of Work for Organic Analysis, OLMO 1.8. Washington, DC.

U.S. Environmental Protection Agency. 1992. Test Methods for Evaluating Solid Waste, Physical/Chemical Methods, SW-846, 3rd Edition. Washington, DC.

U.S. Environmental Protection Agency. 1993. Contract Laboratory Program Statement of Work for Inorganic Analysis, ILMO 3.0. Washington, DC.

U.S. Environmental Protection Agency. 1994a. Contract Laboratory Program Statement of Work for Inorganics Analysis, ILMO 4.0. Washington, DC.

U.S. Environmental Protection Agency. 1994b. Contract Laboratory Program Statement of Work for Organics Analysis, OLMO 3.1. Washington, DC. 
U.S. Environmental Protection Agency. 1994c. Guidance for the Data Quality Objectives Process, EPA QA/G-4. Washington, DC.

U.S. Environmental Protection Agency. 1996. Test Methods for Evaluating Solid Waste, Physical/Chemical Methods, SW-846, 3rd Edition, CD ROM includes 1986, 1992, and 1994 revisions. Washington, DC.

U.S. Environmental Protection Agency. 1998. Region IX Preliminary Remediation Goals. Memorandum from S.J. Smucker, 1998. San Francisco, CA.

U.S. Nuclear Regulatory Commission. 1997. Multiagency Radiation Survey and Site Investigation Manual (MARSSIM), NUREG-1575/EPA 402-R-97-016. Prepared by the NRC, EPA, DOE, and DoD. Washington, DC: U.S. Government Printing Office.

Winograd, I.J., and W. Thordarson. 1975. Hydrologic and Hydrochemical Framework, South-Central Great Basin, Nevada-California, with Special Reference to the Nevada Test Site, U.S. Geological Survey Professional Paper 712C. Washington, DC: U.S. States Government Printing Office. 


\section{Appendix A}

\section{Data Quality Objectives Worksheets}




\section{A.1.0 Introduction}

\section{A.1.1 Problem Statement}

Hydrocarbons and potentially hazardous wastes (lead) may have been released at the Fuel Storage Area, CAU 321 (CAS 22-99-05). Existing information about the nature and extent of potential contamination is insufficient to evaluate and select preferred corrective actions for these sites.

The CAU 321 Fuel Storage Area investigation will be based on the DQOs developed by representatives of NDEP and DOE/NV. This investigation will determine if COPCs are present and if concentrations exceed preliminary action levels in soils within the Fuel Storage Area. If COPCs are detected, the lateral and vertical extent of contamination will be delineated. Data adequate to close the site under State of Nevada regulations, RCRA, and DOE requirements will be collected.

\section{A.1.2 DQO Kickoff Meeting}

Table A.1-1 lists the participants present at the FFACO-required DQO Kickoff Meeting and any subsequent meetings. The goal of the DQO process is to establish the quantity and quality of environmental data required to support corrective action decisions for the CAUs. The process ensures that the information collected will provide sufficient and reliable information to identify, evaluate, and technically defend the chosen corrective action. 
Table A.1-1

DQO Kickoff Meeting Participants

\begin{tabular}{||l|l|c|}
\hline \multirow{2}{*}{\multicolumn{1}{|c|}{ Participant }} & Affiliation & Meeting Date \\
\cline { 3 - 3 } & & $\begin{array}{c}\text { Kickoff Meeting } \\
\text { October 15, 1998 }\end{array}$ \\
\hline \hline Robert Curiale & IT & $\mathrm{X}$ \\
\hline Sabine Curtis & DOE/NV & $\mathrm{X}$ \\
\hline Mark DiStefano & IT & $\mathrm{X}$ \\
\hline Syl Hersh & IT & $\mathrm{X}$ \\
\hline Clemens Goewert & NDEP & $\mathrm{X}$ \\
\hline Juliana Herrington & SAIC & $\mathrm{X}$ \\
\hline Dave Madsen & BN & $\mathrm{X}$ \\
\hline Dudley Emer & BN & $\mathrm{X}$ \\
\hline Francesca Cenicola & BN & $\mathrm{X}$ \\
\hline Elizabeth Hill & SAIC & $\mathrm{X}$ \\
\hline Mary Todd & SAIC & $\mathrm{X}$ \\
\hline Jeanne Wightman & MACTEC & $\mathrm{X}$ \\
\hline
\end{tabular}

BN - Bechtel Nevada

DOE/NV - U.S. Department of Energy, Nevada Operations Office

IT - IT Corporation

MACTEC - Management Analysis Company Technologies

NDEP - Nevada Division of Environmental Protection

SAIC - Science Applications International Corporation 


\section{A.2.0 Conceptual Model}

The CAU 321 Fuel Storage Area was used to store the petroleum, oil, and lubricants needed for the Camp Desert Rock facility at Area 22 of the NTS, Nevada. The CAU 321 site is shown as a petroleum, oil, and lubricants dump on basic information maps for the Camp Desert Rock facility (USACE, 1958). The Camp Desert Rock facility was actively used by the Sixth Army Installation for housing military personnel taking part in military exercises at the NTS from1951 to1958. The Camp Desert Rock facility was dismantled after 1958 (DOE/NV, 1996a). The Fuel Storage Area is a bermed area approximately 165 by $99 \mathrm{~m}$ (540 by $325 \mathrm{ft}$ ). Section 2.0 of the CAIP describes the Fuel Storage Area, operational history, waste inventories, release information, and investigative backgrounds.

The conceptual model for the CAU 321 Fuel Storage Area is provided in Table A.2-1. 
Table A.2-1

Conceptual Model Element Descriptions

\begin{tabular}{|c|c|c|}
\hline $\begin{array}{l}\text { Conceptual Model } \\
\text { Element }\end{array}$ & Description & Source \\
\hline \multirow{3}{*}{$\begin{array}{l}\text { Fuel Storage Area } \\
\text { (CAS 22-99-05) }\end{array}$} & $\begin{array}{l}\text { The CAU } 321 \text { Fuel Storage Area is located at Area } 22 \text { of the } \\
\text { NTS. }\end{array}$ & $\begin{array}{l}\text { Engineering drawings } \\
\text { (USACE, 1958), } \\
\text { Process knowledge } \\
\text { (DOE/NV, 1996a), } \\
\text { Aerial photographs } \\
\text { (RSL, 1955) }\end{array}$ \\
\hline & Graded and bermed area 165 by $99 \mathrm{~m}$ (540 by $325 \mathrm{ft}$ ). & $\begin{array}{l}\text { Aerial photographs } \\
\text { (RSL, 1955), } \\
\text { Engineering drawings } \\
\text { (USACE, 1958) }\end{array}$ \\
\hline & $\begin{array}{l}\text { Camp Desert Rock facility operational from } 1951 \text { to } 1958 \text { and } \\
\text { then dismantled. }\end{array}$ & $\begin{array}{l}\text { Process knowledge } \\
\text { (DOE/NV, 1996a) }\end{array}$ \\
\hline \multirow{3}{*}{ Evidence for COPCs } & $\begin{array}{l}\text { The site was used for the storage for petroleum, oil, and } \\
\text { lubricants. If COPCs are present, they would most likely be } \\
\text { associated petroleum hydrocarbons. }\end{array}$ & $\begin{array}{l}\text { Engineering drawings } \\
\text { (USACE, 1958) }\end{array}$ \\
\hline & $\begin{array}{l}\text { One relatively small area shows some discoloration. } \\
\text { Otherwise, there is no visible staining or odors at the site. No } \\
\text { evidence of underground storage tanks. }\end{array}$ & $\begin{array}{l}\text { Visual observation, } \\
\text { Geophysical surveys } \\
\text { (BN, 1998) }\end{array}$ \\
\hline & $\begin{array}{l}\text { Areas of ponding are evident in a } 1955 \text { aerial photograph } \\
\text { SC510958; the actual liquid is unknown. }\end{array}$ & $\begin{array}{l}\text { Aerial photograph } \\
\text { (RSL, 1955), } \\
\text { Process knowledge }\end{array}$ \\
\hline \multirow{4}{*}{ Extent of COPCs } & $\begin{array}{l}\text { If COPCs released at the site, assume relatively low } \\
\text { contaminant concentrations due to biodegradation of } \\
\text { petroleum products. }\end{array}$ & $\begin{array}{l}\text { Degradation due to } \\
\text { natural biological } \\
\text { processes }\end{array}$ \\
\hline & $\begin{array}{l}\text { The extent of lateral contamination, if present, is not } \\
\text { expected beyond the bermed area of the site. Any releases } \\
\text { at the site are most likely due to accidental spills and not } \\
\text { deliberate disposal. }\end{array}$ & $\begin{array}{l}\text { Aerial photograph } \\
\text { (RSL, 1955) }\end{array}$ \\
\hline & $\begin{array}{l}\text { Minor vertical extent. No underground pipes or underground } \\
\text { storage tanks have been identified. }\end{array}$ & $\begin{array}{l}\text { Geophysical survey } \\
(\mathrm{BN}, 1998)\end{array}$ \\
\hline & $\begin{array}{l}\text { The site was used for hydrocarbon storage for a limited } \\
\text { amount of time (1951 to 1958). Annual precipitation is not } \\
\text { adequate to cause appreciable downward contaminant } \\
\text { movement. }\end{array}$ & $\begin{array}{l}\text { Aerial photograph } \\
\text { (RSL, 1955), } \\
\text { Process knowledge } \\
\text { (DOE/NV, 1996a) }\end{array}$ \\
\hline Future use of the site & Restricted per the NTS Environmental Impact Statement & $\begin{array}{l}\text { Environmental Impact } \\
\text { Statement (DOE/NV, } \\
\text { 1996a) }\end{array}$ \\
\hline Potential receptors & Site workers & $\begin{array}{l}\text { NTS excavation } \\
\text { activities }\end{array}$ \\
\hline
\end{tabular}




\section{A.3.0 Potential Contaminants}

Section 3.0 of the CAIP provides additional information on the COPCs for the CAU 321 Fuel Storage Area, including PALs and QA/QC requirements (see Table A.3-1 of this appendix and Table 3-1 of the CAIP).

The COPCs for the Fuel Storage Area are:

- Hydrocarbons associated with the Fuel Storage Area for the historic Camp Desert Rock facility may include petroleum, oil, and lubricants. Only trace amounts of these products are expected (if present at all). Table A.3-1 identifies the COPCs for CAU 321.

- Other COPCs for this site include VOCs, SVOCs, total lead, TCLP lead, and radiological emitters. These COPCs will be evaluated through field screening, field survey, and/or limited laboratory analyses for one or more of the following reasons:

- Potential for being associated with petroleum products (e.g., lead may be associated with leaded fuel)

- Evaluated as a precautionary measure because of operations associated with a nuclear testing facility

- Evaluated for waste management purposes 
Table A.3-1

CAU 321 Fuel Storage Area

Contaminants of Potential Concern

\begin{tabular}{|c|c|c|c|c|c|c|c|c|c|c|}
\hline Analyte & Comments & $\begin{array}{l}\text { Field } \\
\text { Screening } \\
\text { Method }\end{array}$ & $\begin{array}{c}\text { Field } \\
\text { Screening } \\
\text { Level }\end{array}$ & $\begin{array}{l}\text { Conduct } \\
\text { Analytical? }\end{array}$ & $\begin{array}{l}\text { Analytical } \\
\text { Method }\end{array}$ & $\begin{array}{c}\text { Practical } \\
\text { Quantitation } \\
\text { Limit } \\
\text { (soil/water) }\end{array}$ & $\begin{array}{l}\text { Preliminary } \\
\text { Action } \\
\text { Level }\end{array}$ & Source $^{c}$ & $\begin{array}{l}\text { Precision } \\
\text { (RPD) }\end{array}$ & $\begin{array}{c}\text { Accuracy } \\
(\% \mathrm{R})\end{array}$ \\
\hline $\begin{array}{l}\text { Volatile } \\
\text { Organic } \\
\text { Compounds }\end{array}$ & $\begin{array}{l}\text { Potential for } \\
\text { petroleum, oil, } \\
\text { and lubricants }\end{array}$ & Headspace & $\begin{array}{l}20 \text { ppm or } 2.5 \mathrm{X} \\
\text { background (use } \\
\text { greater value) }\end{array}$ & Yes $^{*}$ & $8260 B^{a}$ & \multirow{6}{*}{ See Table 3-1 } & $\mathrm{PRGs}^{\mathrm{b}}$ & NAC 445A & \multirow{6}{*}{\multicolumn{2}{|c|}{ See Table 3-1 }} \\
\hline $\begin{array}{l}\text { Semivolatile } \\
\text { Organic } \\
\text { Compounds }\end{array}$ & $\begin{array}{l}\text { Potential for } \\
\text { petroleum, oil, } \\
\text { and lubricants }\end{array}$ & $\mathrm{N} / \mathrm{A}$ & $\mathrm{N} / \mathrm{A}$ & Yes $^{*}$ & $8270 C^{a}$ & & $\mathrm{PRGs}^{\mathrm{b}}$ & NAC 445A & & \\
\hline $\begin{array}{l}\text { Total } \\
\text { Petroleum } \\
\text { Hydrocarbons }\end{array}$ & $\begin{array}{l}\text { Potential for } \\
\text { petroleum, oil, } \\
\text { and lubricants }\end{array}$ & Hanby ${ }^{\mathrm{TM}}$ & $>100$ ppm & Yes $^{*}$ & 8015B modified ${ }^{a}$ & & $100 \mathrm{mg} / \mathrm{kg}^{\mathrm{b}, \mathrm{g}}$ & NAC 445A & & \\
\hline Total Lead & $\begin{array}{l}\text { Potential for } \\
\text { leaded } \\
\text { hydrocarbon } \\
\text { products }\end{array}$ & $\mathrm{N} / \mathrm{A}$ & $\mathrm{N} / \mathrm{A}$ & Yes $^{*}$ & $6010 \mathrm{~B}^{\mathrm{a}}$ & & $1,000 \mathrm{mg} / \mathrm{kg}^{\mathrm{b}}$ & NAC 445A & & \\
\hline TCLP Lead & $\begin{array}{l}\text { Potential for } \\
\text { leaded } \\
\text { hydrocarbon } \\
\text { products }\end{array}$ & $N / A$ & $\mathrm{~N} / \mathrm{A}$ & Yes* $^{*}$ & $1311^{t} / 6010 \mathrm{~B}^{\mathrm{a}}$ & & $5 \mathrm{mg} / \mathrm{L}$ & $\begin{array}{l}40 \text { CFR } \\
261.24\end{array}$ & & \\
\hline Radionuclides & $\begin{array}{l}\text { Not anticipated, } \\
\text { precautionary } \\
\text { measure, waste } \\
\text { management }\end{array}$ & $\begin{array}{l}\text { Electra (alpha/ } \\
\text { beta scintillator) }\end{array}$ & $\begin{array}{l}\text { Mean plus } 2 \\
\text { standard } \\
\text { deviations of } 20 \\
\text { surficial- } \\
\text { background } \\
\text { readings }\end{array}$ & $\begin{array}{l}\text { Only if field } \\
\text { screening } \\
\text { level is } \\
\text { exceeded }\end{array}$ & $\begin{array}{l}\text { Gamma } \\
\text { Spectroscopy } \\
\text { Method }^{d}\end{array}$ & & $\begin{array}{l}\text { Mean activity } \\
\text { plus } 2 \text { times } \\
\text { standard } \\
\text { deviation of } \\
\text { background } \\
\text { samples }\end{array}$ & $\begin{array}{l}\text { NUREG- } \\
1575^{\mathrm{e}}\end{array}$ & & \\
\hline
\end{tabular}

a Test Methods for Evaluating Solid Waste, Third Edition, Parts 1-4, SW-846 (EPA, 1996)

${ }^{\mathrm{b}}$ Region IX Preliminary Remediation Goals (PRGs) (EPA, 1998)

'NDEP Corrective Action Regulations (NAC, 1997)

${ }^{\mathrm{d} G a m m a-R a y ~ S p e c t r o m e t r y ~ O p e r a t i o n s ~(B N, ~ 1996) ~ o r ~ e q u i v a l e n t ~ m e t h o d ~ o r ~ e q u i v a l e n t ~}$

eU.S. Nuclear Regulatory Commission (NRC) Multiagency Radiation Survey and Site Investigation Manual (NRC, 1997)

${ }^{\dagger}$ Test Methods for Evaluating Solid Waste, 3rd Edition, Parts 1-4, SW-846 (EPA, 1992)

g 40 CFR 261.24 (CFR, 1998a)

${ }^{*}$ As specified in text Section 3.0 of the CAIP 


\section{A.4.0 Decisions and Inputs}

\section{A.4.1 Decisions}

Decisions to be resolved by the investigation include:

- Determine the presence or absence of COPCs.

- If COPCs are present, determine whether COPC concentrations exceed field screening levels.

- If COPCs are present, determine whether COPC concentrations exceed PALs.

- Determine the nature and extent of contamination (or absence of contamination) with enough certainty to develop and evaluate a range of potential corrective actions, including closure in place and clean closure.

\section{A.4.2 Inputs and Strategy}

Inputs are those elements of information used to support the decisions in addressing the identified problem. A list of information inputs, existing data, identified data gaps, and brief strategies are discussed in Table A.4-1. A more detailed discussion of investigation strategies is found in Section A.5.0. 
Table A.4-1

Decisions, Inputs, and General Strategies

(Page 1 of 3 )

\begin{tabular}{|c|c|c|c|c|}
\hline Decision & Input & Existing Data & Data Gap & Strategy \\
\hline \multirow[b]{3}{*}{$\begin{array}{l}\text { Are COPCs present } \\
\text { above PALs at site? }\end{array}$} & $\begin{array}{l}\text { Potential contaminant } \\
\text { identification }\end{array}$ & $\begin{array}{l}\text { Process knowledge of product } \\
\text { storage }\end{array}$ & Exact COPCs & $\begin{array}{l}\text { Collect laboratory samples and } \\
\text { analyze for COPCs. }\end{array}$ \\
\hline & $\begin{array}{l}\text { Potential contaminant } \\
\text { concentration }\end{array}$ & $\begin{array}{l}\text { Preliminary assessments } \\
\text { sampling data available } \\
\text { from two sampling locations }\end{array}$ & $\begin{array}{l}\text { Identify COPCs and } \\
\text { concentrations }\end{array}$ & $\begin{array}{l}\text { Collect soil samples with a direct- } \\
\text { push method (e.g., Geoprobe }{ }^{\mathrm{TM}} \text { ) for } \\
\text { field screening and laboratory } \\
\text { analyses. Soil sample locations will } \\
\text { be statistically selected. Biased soil } \\
\text { samples will also be collected from } \\
\text { areas that represent worst case for } \\
\text { contamination; compare results to } \\
\text { field screening levels and/or to } \\
\text { PALs. }\end{array}$ \\
\hline & $\begin{array}{l}\text { Potential contaminant } \\
\text { distribution }\end{array}$ & $\begin{array}{l}\text { Location of the Fuel Storage } \\
\text { Area is known. The vertical } \\
\text { and lateral extent of COPCs is } \\
\text { assumed to be limited and } \\
\text { only minor in nature. COPCs } \\
\text { exist in only relatively low } \\
\text { concentrations. A significant } \\
\text { amount of time has passed } \\
\text { (approximately } 40 \text { years). } \\
\text { There is a lack of driving force } \\
\text { due to arid environment. } \\
\text { COPCs are relatively } \\
\text { immobile. }\end{array}$ & $\begin{array}{l}\text { Identify vertical and lateral } \\
\text { extent of COPCs }\end{array}$ & $\begin{array}{l}\text { Use direct-push method } \\
\left.\text { (e.g., Geoprobe }{ }^{\mathrm{TM}}\right) \text { to collect soil } \\
\text { samples to establish the presence } \\
\text { and extent of COPCs. Field screen/ } \\
\text { survey for VOCs, TPH, and } \\
\text { radiological emitters at } 1 \mathrm{ft} \text { and } 2 \mathrm{ft} \text {. } \\
\text { If field screening results are > FSLs, } \\
\text { then continue sampling at } 2 \mathrm{ft} \\
\text { intervals to a maximum of } 10 \mathrm{ft} \text { bgs } \\
\text { or until two-consecutive nondetect } \\
\text { results have been obtained. If } \\
\text { COPCs are above FSLs then submit } \\
\text { a soil sample from location with the } \\
\text { highest field screen result and from } \\
\text { the first nondetect sample interval for } \\
\text { laboratory analyses. }\end{array}$ \\
\hline
\end{tabular}


Table A.4-1

Decisions, Inputs, and General Strategies

(Page 2 of 3 )

\begin{tabular}{|c|c|c|c|c|}
\hline Decision & Input & Existing Data & Data Gap & Strategy \\
\hline \multirow{6}{*}{$\begin{array}{l}\text { Are potential } \\
\text { contaminants } \\
\text { migrating? }\end{array}$} & $\begin{array}{l}\text { Relative mobility of potential } \\
\text { contaminant }\end{array}$ & $\begin{array}{l}\text { TPH volume unknown and is } \\
\text { assumed to be relatively } \\
\text { small; limited migration at } \\
\text { similar sites }\end{array}$ & $\begin{array}{l}\text { Identify COPCs and } \\
\text { concentrations }\end{array}$ & As discussed above. \\
\hline & $\begin{array}{l}\text { Potential contaminant } \\
\text { distribution }\end{array}$ & $\begin{array}{l}\text { Limited by contaminant- } \\
\text { specific, geological, } \\
\text { operational, and } \\
\text { meteorological characteristics }\end{array}$ & $\begin{array}{l}\text { Identify vertical and lateral } \\
\text { extent of COPCs }\end{array}$ & As discussed above. \\
\hline & Meteorologic data & $\begin{array}{l}\text { NTS and Yucca Mountain } \\
\text { data on annual precipitation, } \\
\text { evapotranspiration, and } \\
\text { weather; weather station } \\
\text { present near the site }\end{array}$ & $\begin{array}{l}\text { Sufficient information should } \\
\text { be available }\end{array}$ & $\begin{array}{l}\text { No site-specific meteorological data } \\
\text { collection will be collected; general } \\
\text { weather conditions and wind speed } \\
\text { and direction are noted on daily field } \\
\text { notes. }\end{array}$ \\
\hline & Geologic/hydrologic data & $\begin{array}{l}\text { General geologic/hydrologic } \\
\text { characteristics of site; specific } \\
\text { geologic conditions of nearby } \\
\text { sites (i.e., CAUs } 340 \text { and } 650 \text { ) }\end{array}$ & No data gap identified & $\begin{array}{l}\text { No specific geologic or hydrologic } \\
\text { sample data will be collected for this } \\
\text { site. Assume mainly near-surface } \\
\text { investigation. General soil } \\
\text { characteristics will be noted on } \\
\text { sample collection log. }\end{array}$ \\
\hline & Biological degradation factors & $\begin{array}{l}\text { Hydrocarbons potentially } \\
\text { released in CAU } 321\end{array}$ & None anticipated & $\begin{array}{l}\text { There are no plans to collect } \\
\text { microbial samples; however, if field } \\
\text { screening results have higher than } \\
\text { expected concentrations, samples } \\
\text { may be collected. }\end{array}$ \\
\hline & Radiological data & $\begin{array}{l}\text { Man-made radionuclides not } \\
\text { expected at this site }\end{array}$ & $\begin{array}{l}\text { None anticipated, but will } \\
\text { conduct precautionary field } \\
\text { survey }\end{array}$ & $\begin{array}{l}\text { Establish background; field screen } \\
\text { for alpha/beta radiation using } \\
\text { Electra instrument; soil samples will } \\
\text { be collected and submitted for } \\
\text { laboratory analyses only if field } \\
\text { screening levels are exceeded (see } \\
\text { Table A.3-1). }\end{array}$ \\
\hline
\end{tabular}


Table A.4-1

Decisions, Inputs, and General Strategies

(Page 3 of 3 )

\begin{tabular}{|c|c|c|c|c|}
\hline Decision & Input & Existing Data & Data Gap & Strategy \\
\hline \multirow{3}{*}{$\begin{array}{l}\text { Data sufficient to } \\
\text { support closure } \\
\text { options? }\end{array}$} & No further action & $\begin{array}{l}\text { There is no historical evidence } \\
\text { of COPCs being released to } \\
\text { the environment. However, } \\
\text { because the site was used to } \\
\text { store petroleum products } \\
\text { there is a potential for fuel } \\
\text { spill(s). }\end{array}$ & $\begin{array}{l}\text { Presence, concentration, and } \\
\text { extent of COPCs }\end{array}$ & $\begin{array}{l}\text { Insufficient evidence to proceed } \\
\text { without investigation. Collect field } \\
\text { and laboratory samples; compare } \\
\text { results to PALs. If no COPCs above } \\
\text { PALs, prepare CADD/CR. }\end{array}$ \\
\hline & $\begin{array}{l}\text { Closure in place by } \\
\text { administrative controls }\end{array}$ & $\begin{array}{l}\text { Potential for TPH and RCRA } \\
\text { constituents; assume } \\
\text { industrial soil PRGs per NAC } \\
445 A \text { (NAC, 1997); assume } \\
100 \text { ppm for TPH per NAC } \\
445 A \text {; assume use } \\
\text { restrictions with signs and } \\
\text { fencing as needed. }\end{array}$ & $\begin{array}{l}\text { Presence of regulated } \\
\text { COPCs; concentrations above } \\
\text { PALs; groundwater protection }\end{array}$ & $\begin{array}{l}\text { Collect field and laboratory samples; } \\
\text { compare results to PALs. If no } \\
\text { COPCs above PALs, prepare } \\
\text { CADD/CR; otherwise prepare } \\
\text { CADD; } \\
\text { A-K analysis. }\end{array}$ \\
\hline & $\begin{array}{l}\text { Clean closure by contaminant } \\
\text { removal }\end{array}$ & $\begin{array}{l}\text { Potential for TPH and RCRA } \\
\text { constituents; assume } \\
\text { industrial PRGs per NAC } \\
445 A \text {; assume } 100 \text { ppm for } \\
\text { TPH per NAC } 445 \mathrm{~A} \text {. }\end{array}$ & $\begin{array}{l}\text { Presence, concentration, and } \\
\text { extent of COPCs; volume of } \\
\text { contaminated material above } \\
\text { PALs }\end{array}$ & $\begin{array}{l}\text { Collect field and laboratory samples; } \\
\text { compare results to PALs. If no } \\
\text { COPCs above PALs, prepare } \\
\text { CADD/CR; otherwise prepare } \\
\text { CADD. }\end{array}$ \\
\hline
\end{tabular}

TPH - Total petroleum hydrocarbons

PRGs - Preliminary Remediation Goal(s)

NAC - Nevada Administrative Code

ppm - Parts per million

PALs - Preliminary Action Level(s)

CADD - Corrective Action Decision Document

CR - Closure Report 


\section{A.5.0 Investigation Strategy}

The strategy for the CAU 321 Fuel Storage Area investigation included conducting a geophysical survey prior to the establishment of a DQO to determine the presence of any underground storage tanks at the site. The results of the survey indicate that no underground storage tanks or pipes are present at the CAU 321 Fuel Storage Area.

The investigation of the CAU 321 Fuel Storage Area will be as follows:

- Geoprobe ${ }^{\mathrm{TM}}$ will be used to collect soil samples for field screening and laboratory analyses.

- Twelve sample locations have been selected statistically (see Section A.7.0, Decision Errors).

- Six additional biased sample locations will be selected at areas suspected of being contaminated and/or at the discretion of the site-supervisor.

- $\quad$ Field screen samples for:

- Total petroleum hydrocarbons at $1 \mathrm{ft}$ and $2 \mathrm{ft}$ using the Hanby ${ }^{\mathrm{TM}}$ Method

- Volatile organic compounds using a photoionization detector

- Field survey for radiological emitters using an Electra alpha/beta scintillator

- At each sample location where COPCs are above the field screening levels then:

- Continue field screening at $2 \mathrm{ft}$ intervals down to $10 \mathrm{ft}$ or until two consecutive nondetect results have been obtained.

- Submit sample with the highest field screening result and the first sample from the two consecutive nondetects (results less than FSLs).

- If COPCs are below the field screening results for all samples for this site then:

- A minimum of 16 nondetect samples will be submitted for laboratory analyses (see Section A.7.0, Decision Errors). 
- Additional samples may be collected and submitted for analyses at the discretion of the site supervisor.

- Step-out sampling may be conducted at the discretion of the site supervisor if lateral extent of contamination needs to be further delineated.

- Additional sampling, including step-out sampling, may be conducted at the discretion of the site supervisor if sample analytical results are inadequate for preparing a CADD.

- If COPCs extend beyond $10 \mathrm{ft}$ then rescope investigation.

- Perform laboratory analyses per Table A.3-1.

- If COPCs are not detected, then prepare CADD/CR. 


\section{A.6.0 Decision Rules}

The following decision rules and logic diagram (Figure A.6-1) are applicable to the CAU 321 Fuel Storage Area and will be used to guide the investigation and subsequent data evaluation:

- If, in the course of the investigation, either of the following occur, then the investigation will be halted and rescoped as necessary:

- The conceptual model fails to such a degree that rescoping is required.

- Sufficient data are collected to support evaluation of corrective actions.

- Soil Field Screening and Sampling:

- If field screening at $1 \mathrm{ft}$ and $2 \mathrm{ft}$ bgs indicate that no COPCs are present above fieldscreening levels for this site, then approximately 16 samples will be submitted for confirmatory laboratory analyses and the subsurface investigation will be halted at the $2 \mathrm{ft}$ bgs. However, at 3 sample locations (to be determined) soil samples will be collected at $4 \mathrm{ft}$ bgs.

- If field screening indicates that COPCs are present above field-screening levels at $1 \mathrm{ft}$ or $2 \mathrm{ft} \mathrm{bgs}$, then field screening will continue at $2 \mathrm{ft}$ intervals (i.e., $4 \mathrm{ft}, 6 \mathrm{ft}, 8 \mathrm{ft}$, and $10 \mathrm{ft}$ ) down to10 $\mathrm{ft}$ bgs until two consecutive samples with field screening results below field screening levels are obtained. Soil samples will be submitted for laboratory analyses from the sample with the highest field screening result and from the first interval of the two consecutive nondetect interval(s) (see Table A.3-1 for analyses).

- If analytical results are not adequate for preparation of a CADD and/or for waste management purposes, then additional sampling including step-out sampling may be conducted and submitted for analyses at the discretion of the Site Supervisor.

- If COPCs extend beyond $10 \mathrm{ft}$ then rescope investigation.

- If laboratory results indicate the presence of COPCs above PALs, then a CADD will be prepared.

- If no COPCs are identified above PALs, then a CADD/CR will be prepared according to the outline agreed upon by NDEP and DOE/NV. 


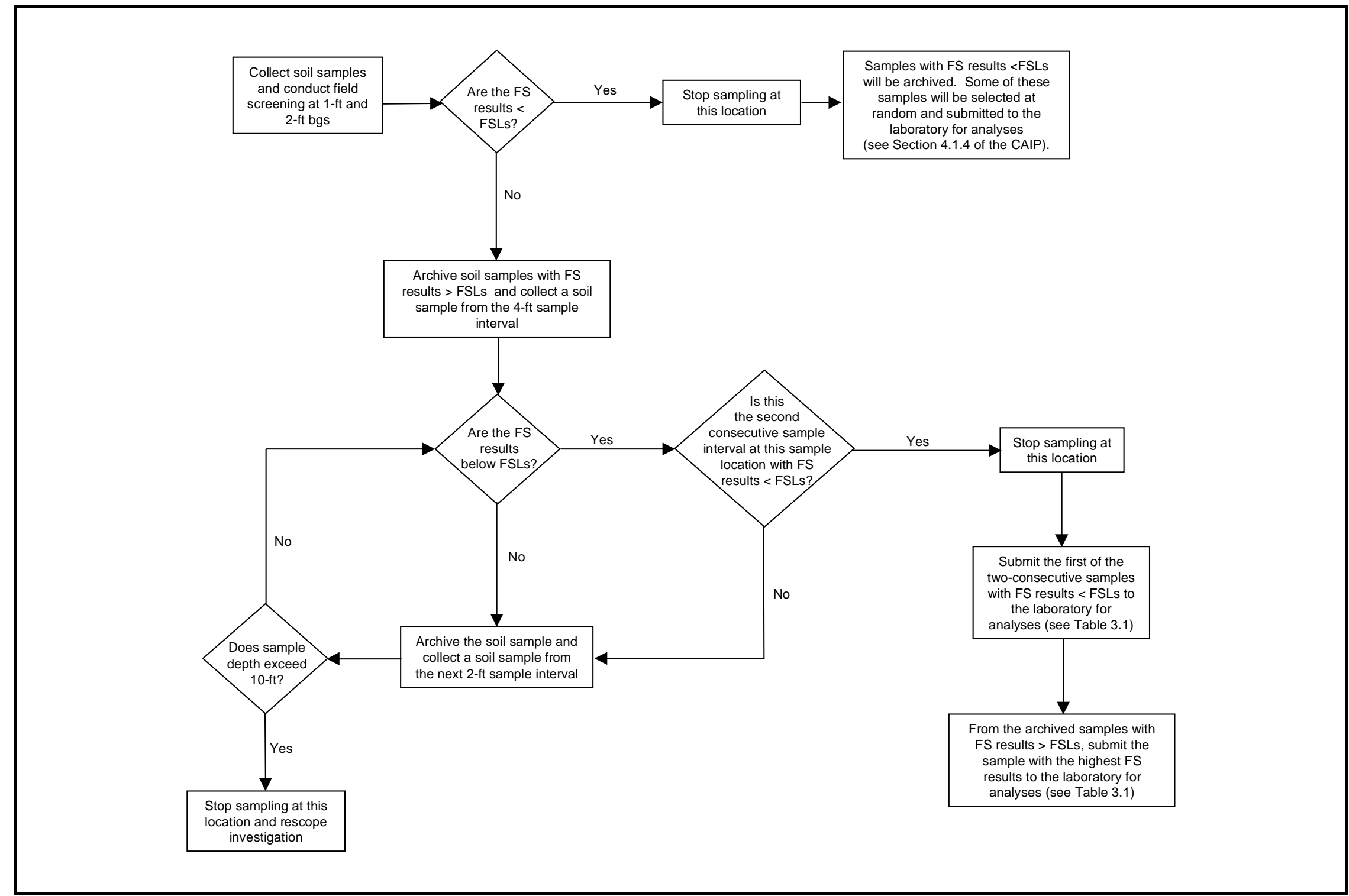

Figure A.6-1

Decision Rule Logic Diagram for CAU 321 Fuel Storage Area Investigation 


\section{A.7.0 Decision Error}

Statistical based and biased sampling locations will be selected for soil sampling at the CAU 321 Fuel Storage Area as identified in Sections A.4.0, A.5.0, and A.6.0. Statistical sampling is appropriate because there is no conclusive evidence of specific point sources (i.e., spills, release, or disposal points). However, biased sampling will also be conducted at areas where ponding may have occurred (e.g., dark areas on photograph) as shown in an 1955 aerial photograph of the Camp Desert Rock facility (RSL, 1955) and at slightly discolored area. Confidence levels and sampling errors are as agreed to by the DOE/NV and the NDEP. The proposed confidence levels and tolerable errors in the estimation of the sample mean were arrived at according to the following reasoning.

\section{A.7.1 Initial Field Screening}

The manufacturer of the Hanby ${ }^{\mathrm{TM}}$ kit claims a CV of 20 percent for soil analyses (Hanby, 1998). A 50 percent $\mathrm{CV}$ (i.e., assuming that the method is not as reproducible as the manufacturer claims) will be assumed; therefore, a greater number of samples will need to be field screened. A 30 percent relative error in the mean will be tolerated, which is considered acceptable (EPA, 1989) for a preliminary site investigation. Because of the large anticipated standard deviation (poor reproducibility) of the field screening method and the fact that a significant relative error in the mean will be tolerated, a confidence limit of 95 percent will be demanded for the preliminary investigation.

Inputting these parameters into standard statistical equations for calculating required numbers of samples results in 12 samples from each stratum (sample interval) to be field-screened. In addition to these statistically selected sample locations, six biased sample locations will be selected in areas where COPCs may have accumulated.

\section{A.7.2 Laboratory Confirmation of Field Screening Nondetections}

The reproducibility of the laboratory method is expected to be significantly better than that of the field screening method; a 20 percent CV for soil analyses by the SW-846 8015 method will be 
assumed. No more than a 10 percent relative error in the mean will be tolerated, which is considered acceptable for planned removal or remedial response operations (EPA, 1989).

Since the reproducibility of the laboratory method should be significantly better than that of the field screening method and a smaller relative error in the mean is demanded, a confidence limit of 95 percent will be tolerated for this phase of the investigation.

Inputting these parameters into standard statistical equations for calculating required numbers of samples results in 16 samples for which field screening indicated that TPH levels were below target levels to be submitted to the off-site laboratory for confirmation. 
Appendix B

\section{Project Organization}




\section{B.1.0 Project Organization}

The DOE/NV Industrial Sites Project Manager is Janet Appenzeller-Wing and her telephone number is (702) 295-0461.

The names of the project Health and Safety Officer and the Quality Assurance Officer can be found in the appropriate DOE/NV plan. However, personnel are subject to change, and it is suggested that the Project Manager be contacted for further information. The Task Manager will be identified in the FFACO Biweekly Activity Report prior to the start of field activities. 


\section{Appendix C}

\section{NDEP Document Review Sheet}




\section{NEVADA ENVIRONMENTAL RESTORATION PROJECT}

DOCUMENT REVIEW SHEET

(Page 1 of 2$)$

\begin{tabular}{|c|c|c|c|c|c|}
\hline \multicolumn{4}{|c|}{$\begin{array}{l}\text { 1. Document Title/Number: Draft Corrective Action Investigation Plan for Corrective Action Unit 321; Area } 22 \\
\text { Weather Station Fuel Storage, Nevada Test Site, nevada }\end{array}$} & \multicolumn{2}{|l|}{ 2. Document Date: 1998} \\
\hline \multicolumn{4}{|c|}{ 3. Revision Number: } & \multicolumn{2}{|c|}{ 4. Originator/Organization: IT Corporation } \\
\hline \multicolumn{4}{|c|}{ 5. Responsible DOE/NV ERP Subproject Mgr.: Janet Appenzeller-Wing } & \multicolumn{2}{|c|}{ 6. Date Comments Due: December 10, 1998} \\
\hline \multicolumn{6}{|c|}{ 7. Review Criteria: Regulatory } \\
\hline \multicolumn{4}{|c|}{ 8. Reviewer/Organization/Phone No.: Clemens Goewert, NDEP, 486-2865 } & \multicolumn{2}{|l|}{ 9. Reviewer's Signature: } \\
\hline $\begin{array}{l}\text { 10. Comment } \\
\text { Number/ } \\
\text { Location }\end{array}$ & 11. Type* & 12. Comment & \multicolumn{2}{|c|}{ 13. Comment Response } & 14. Accept \\
\hline $\begin{array}{l}\text { Page } 8 \text {, } \\
\text { Sect. } 2.2\end{array}$ & & $\begin{array}{l}\text { Operational History“...Little is known about the details of the } \\
\text { operational history of the site..... There had to be some information } \\
\text { to determine that this was a fuel storage area. Some operational } \\
\text { history is presented in Section } 2.0 \text {, Facilities Description, and should } \\
\text { be moved to this section. }\end{array}$ & \multicolumn{2}{|c|}{ Change made as indicated. } & Accept \\
\hline $\begin{array}{l}\text { Page 13, } \\
\text { Sect. 3.3.3 }\end{array}$ & & $\begin{array}{l}\text { Radiological Preliminary Action Levels } \\
\text { This section proposes to use the Multi-Agency Radiation Survey } \\
\text { and Site Investigation Manual (MARSSIM) (NRC, 1997) to define } \\
\text { Preliminary Action Levels (PALS) for radionuclides. } \\
\text { Since radiological contamination is not expected at this site, less } \\
\text { extensive methods for establishing radiological PALs that have been } \\
\text { established for use at other Corrective Action Sites should be used, } \\
\text { such as mean plus two standard deviations. }\end{array}$ & \multicolumn{2}{|c|}{$\begin{array}{l}\text { Text was modified to state, "Radiological contamination is } \\
\text { not expected at this site. However, as a precautionary } \\
\text { measure alpha/beta radiological field surveys will be } \\
\text { conducted as specified in Section } 3.3 .1 \text {. If the alpha/beta } \\
\text { field survey results exceed the field screening levels then } \\
\text { gamma spectroscopy will be conducted at an off-site } \\
\text { laboratory. The preliminary action levels for gamma } \\
\text { spectroscopy are isotope specific and will be based on the } \\
\text { mean isotopic concentration plus two standard deviations of } \\
\text { the mean based on sample readings taken from background } \\
\text { samples collected at locations within the vicinity of the CAU } \\
321 \text { site. These sample background locations may include } \\
\text { sample readings from Area 23." }\end{array}$} & $\begin{array}{l}\text { Accept with } \\
\text { some } \\
\text { modifica- } \\
\text { tions }\end{array}$ \\
\hline $\begin{array}{l}\text { Page 16, } \\
\text { Sect. 4.1.1.1 }\end{array}$ & & $\begin{array}{l}\text { Field Screening Confidence Levels for the Hanby Method } \\
\text { The detection limit(s) of the Hanby Kit should be specified in this } \\
\text { section. }\end{array}$ & \multicolumn{2}{|c|}{$\begin{array}{l}\text { Change made as indicated. The Hanby detection limits } \\
\text { range from }<1 \mathrm{ppm} \text { to }>1000 \mathrm{ppm} \text {. }\end{array}$} & Accept \\
\hline
\end{tabular}


NEVADA ENVIRONMENTAL RESTORATION PROJECT

DOCUMENT REVIEW SHEET

(Page 2 of 2)

\begin{tabular}{|l|l|l|l|}
\hline $\begin{array}{l}\text { 10. Comment } \\
\text { Lumber/ } \\
\text { Location }\end{array}$ & 11. Type* & 12. Comment & 13. Comment Response \\
\hline \hline $\begin{array}{l}\text { Page 21, } \\
\text { Sect. 5.0 }\end{array}$ & & $\begin{array}{l}\text { The third paragraph states that the wastes will be managed in } \\
\text { accordance with NACs. This should be changed to NRSs, which } \\
\text { are the regulations and not the law. }\end{array}$ & $\begin{array}{l}\text { Comment noted. It is our understanding that the NRS } \\
\text { contains all statute laws of Nevada and the NAC contains all } \\
\text { permanent regulations of the State. }\end{array}$ \\
\hline
\end{tabular}

${ }^{a}$ Comment Types: $M=$ Mandatory, $S=$ Suggested

Return Document Review Sheets to DOE/NV Environmental Restoration Division, Attn: QAC, M/S 505. 


\section{Distribution}

*Provide copy in distribution of Rev. 0 and subsequent revisions if applicable. Copies of only the NDEP-approved document will be distributed to others.

Paul J. Liebendorfer

State of Nevada

Bureau of Federal Facilities

Division of Environmental Protection

333 W. Nye Lane, Room 138

Carson City, NV 89706-0851

Michael McKinnon

State of Nevada

Bureau of Federal Facilities

Division of Environmental Protection

555 E. Washington, Suite 4300

Las Vegas, NV 89101

Sabrina Lawrence

Environmental Restoration Division

DOE/Nevada Operations Office

P.O. Box 98518, M/S 505

Las Vegas, NV 89193-8518

Janet Appenzeller-Wing

Environmental Restoration Division

DOE/Nevada Operations Office

P.O. Box 98518, M/S 505

Las Vegas, NV 89193-8518

Sabine Curtis

Environmental Restoration Division

DOE/Nevada Operations Office

P.O. Box 98518, M/S 505

Las Vegas, NV 89193-8518

Steve Nacht

Bechtel Nevada

P.O. Box 98521, M/S NTS306

Las Vegas, NV 89193-8521
2 (Controlled)*

1 (Controlled)*

1 (Controlled)*

1 (Uncontrolled)*

1 (Uncontrolled)*

1 (Uncontrolled)* 
Dave Madsen

Bechtel Nevada

P.O. Box 98521, M/S NTS306

Las Vegas, NV 89193-8521

Francesca Cenicola

Bechtel Nevada

P.O. Box 98521, M/S NTS306

Las Vegas, NV 89193-8521

Dustin Wilson

SAIC

P.O. Box 93838

Las Vegas, NV 89193

IT Corporation Central Files

P.O. Box 93838

Las Vegas, NV 89193

Juliana Herrington

SAIC

P.O. Box 93838

Las Vegas, NV 89193

Mary Todd

SAIC

P.O. Box 93838

Las Vegas, NV 89193

Technical Information Resource Center

DOE/Nevada Operations Office

P.O. Box 98518, M/S 505

Las Vegas, NV 89193-8518

U.S. Department of Energy

Office of Scientific and Technical Information

P.O. Box 62

Oak Ridge, TN 37831

Manager Southern Nevada FFACO

Public Reading Room

P.O. Box 98521, M/S NLV040

Las Vegas, NV 89193-8521
1 (Uncontrolled)*

1 (Uncontrolled)*

1 (Uncontrolled)*

1 (Uncontrolled)*

1 (Controlled)*

1 (Uncontrolled)*

1 (Uncontrolled)

1 (Uncontrolled, electronic copy)

1 (Controlled)

1 (Uncontrolled) 
Manager Northern Nevada FFACO

Public Reading Room

c/o Rosa Silver

IT Corporation

P.O. Box 93838

Las Vegas, NV 89193

FFACO Public Reading Room Coordinator

Rosa Silver

IT Corporation

P.O. Box 93838

Las Vegas, NV 89193
1 (Uncontrolled)

1 (Controlled) 